\title{
A Full Year Evaluation of the CALIOPE-EU Air Quality Modeling System over Europe for 2004
}

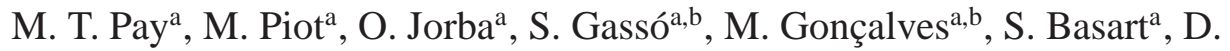 \\ Dabdub $^{\text {d }}$, P. Jiménez-Guerrero ${ }^{\mathrm{c}}$, J. M. Baldasano ${ }^{\mathrm{a}, \mathrm{b}, *}$ \\ jose.baldasano@bsc.es \\ ${ }^{a}$ Earth Sciences Department. Barcelona Supercomputing Center. Barcelona, Spain \\ ${ }^{b}$ Environmental Modelling Laboratory, Technical University of Catalonia, Barcelona, Spain \\ ${ }^{c}$ Now at: Department of Physics, University of Murcia, Murcia, Spain \\ ${ }^{d}$ Department of Mechanical and Aerospace Engineering, University of California, Irvine. \\ California, USA
}

\begin{abstract}
The CALIOPE-EU high-resolution air quality modeling system, namely WRFARW/HERMES-EMEP/CMAQ/BSC-DREAM8b, is developed and applied to Europe $(12 \mathrm{~km} \times 12 \mathrm{~km}, 1 \mathrm{hr})$. The model performances are tested in terms of air quality levels and dynamics reproducibility on a yearly basis. The present work describes a quantitative evaluation of gas phase species $\left(\mathrm{O}_{3}, \mathrm{NO}_{2}\right.$ and $\left.\mathrm{SO}_{2}\right)$ and particulate matter (PM2.5 and PM10) against ground-based measurements from the EMEP (European Monitoring and Evaluation Programme) network for the year 2004. The evaluation is based on statistics. Simulated $\mathrm{O}_{3}$ achieves satisfactory performances for both daily mean and daily maximum concentrations, especially in summer, with annual mean correlations of 0.66 and 0.69 , respectively. Mean normalized errors are comprised within the recommendations proposed by the United States Environmental Protection Agency (US-EPA). The general trends and daily variations of primary pollutants $\left(\mathrm{NO}_{2}\right.$ and $\left.\mathrm{SO}_{2}\right)$ are satisfactory. Daily mean concentrations of $\mathrm{NO}_{2}$ correlate well with observations (annual correlation $\mathrm{r}=0.67$ ) but tend to be underestimated. For $\mathrm{SO}_{2}$, mean concentrations are well simulated (mean bias $=0.5 \mu \mathrm{g} \mathrm{m}^{-3}$ ) with relatively high annual mean correlation $(\mathrm{r}=0.60)$, although peaks are generally overestimated. The dynamics of PM2.5 PM2.5 and PM10 is well reproduced $(0.49<\mathrm{r}<0.62)$, but mean concentrations
\end{abstract}

*Corresponding author. Tel.: +34 9341377 19; fax: +34 934137721

Email address: jose.baldasano@bsc.es (J. M. Baldasano) 
remain systematically underestimated. Deficiencies in particulate matter source characterization are discussed. Also, the spatially distributed statistics and the general patterns for each pollutant over Europe are examined. The model performances are compared with other European studies. While $\mathrm{O}_{3}$ statistics generally remain lower than those obtained by the other considered studies, statistics for $\mathrm{NO}_{2}, \mathrm{SO}_{2}, \mathrm{PM} 2.5$ and PM10 present higher scores than most models.

Keywords: Air quality, Model evaluation, Europe, High resolution, Ozone, Particulate matter

\section{Introduction}

Atmospheric pollutants have significant impact on many main fields. One of the major areas impacted is human health. High correlations between longterm exposure to fine particles and human health issues have been detected in population-based studies for several decades (Lave and Seskin, 1970; Thibodeau et al., 1980; Lipfert, 1994; Pénard-Morand et al., 2005). The latest studies even quantify the effects of aerosols on human lifespan. It is suggested that a decrease of $10 \mu \mathrm{g} \mathrm{m}^{-3}$ in the concentration of fine particles may lead to an increase in life expectancy of 0.61 years (Pope et al., 2009). Another major area impacted by atmospheric pollutants is climate change. Particles scatter and absorb solar and infrared radiation in the atmosphere. In addition, they alter the formation and precipitation efficiency of liquid-water, ice and mixed-phase clouds (Ramanathan et al., 2001). Radiative forcing associated with these perturbations affects climate (Chylek and Wong, 1995; Jacobson, 2001). A third area impacted by air quality pollutants is atmospheric visibility. Since the size of atmospheric aerosols is similar to the wavelength of visible light, light is scattered and absorbed as it travels through the atmosphere (Japar et al., 1986; Adams et al., 1990). In brief, atmospheric pollutants are part of a highly complex system that affects the physics, chemistry, and life on the planet.

The European Commission (EC) and the US-EPA, among others, have shown great interest in the transport and dynamics of pollutants in the atmosphere. According to the European directives (European Commission, 1996, 2008), air quality modeling is a useful tool to understand the dynamics of air pollutants, to analyze and forecast the air quality, and to develop plans reducing emissions and alert the population when health-related issues occur. Both have set ambient air quality standards for acceptable levels of $\mathrm{O}_{3}$ (European Commission, 2002), $\mathrm{NO}_{2}$ and $\mathrm{SO}_{2}$ (European Commission, 1999, 2001), PM2.5 and PM10 in ambient air 
(European Commission, 1999, 2001, 2008).

The CALIOPE project, funded by the Spanish Ministry of the Environment and Rural and Marine Affairs (Ministerio de Medio Ambiente y Medio Rural y Marino), has the main objective to establish an air quality forecasting system for Spain (Baldasano et al., 2008b). In this framework, a high-resolution air quality forecasting system, namely WRF-ARW/HERMES-EMEP/CMAQ/BSCDREAM8b, has been developed and applied to Europe $(12 \mathrm{~km} \times 12 \mathrm{~km}, 1 \mathrm{hr})$ as well as to Spain $(4 \mathrm{~km} \times 4 \mathrm{~km}, 1 \mathrm{hr})$. The simulation of such a high-resolution model system has been made possible by its implementation on the MareNostrum supercomputer hosted by the Barcelona Supercomputing Center-Centro Nacional de Supercomputación (BSC-CNS). In order to reduce uncertainties, the model system is evaluated with observational data to assess its capability of reproducing air quality levels and the related dynamics.

A partnership of four Spanish research institutes composes the CALIOPE project: the BSC-CNS, the "Centro de Investigaciones Energéticas, Medioambientales y Tecnológicas" (CIEMAT), the Institute of Earth Sciences Jaume Almera of the "Centro Superior de Investigaciones Científicas" (IJA-CSIC) and the "Centro de Estudios Ambientales del Mediterraneo" (CEAM). This consortium deals with both operational and scientific aspects related to air quality monitoring and forecasting. BSC-CNS and CIEMAT lead the model developments of the project while IJA-CSIC and CEAM are in charge of retrieving observational data for evaluation processes. Current experimental forecasts are available through http://www.bsc.es/caliope.

Several operational air quality forecasting systems already exist in Europe (see http://gems.ecmwf.int or http://www.chemicalweather.eu, Hewitt and Griggs, 2004; COST, 2009). CALIOPE advances our understanding of atmospheric dynamics in Europe as follows. First, CALIOPE includes a high-resolution computational grid. Most models use a horizontal cell resolution of at least $25 \mathrm{~km} \times$ $25 \mathrm{~km}$ for domains covering continental Europe. CALIOPE uses a $12 \mathrm{~km} \times 12$ $\mathrm{km}$ cell resolution to simulate the European domain. Second, CALIOPE includes a complex description of the processes involved in the modeling of particulate matter. Both are important factors to obtain accurate results of air pollutant concentrations in a complex region such as southern Europe (Jiménez et al., 2006). Moreover, to date, none of the existing European operational systems include the influence of Saharan dust on a non-climatic basis. Dust peaks cannot be represented by introducing boundary conditions derived from dust climatological data due to the highly episodic nature of the events in the region (1- to 4-day average duration) (Jiménez-Guerrero et al., 2008). When considering only anthropogenic 
emissions, chemical transport model simulations underestimate the PM10 concentrations by $30-50 \%$, using the current knowledge about aerosol physics and chemistry (Vautard et al., 2005a).

The purpose of the present paper is to provide a quantitative assessment of the capabilities of the WRF-ARW/HERMES-EMEP/CMAQ/BSC-DREAM8b air quality modeling system to simulate background concentrations of gas and particulate phase in the European domain. In the rest of the paper, this model system will be named "CALIOPE-EU". This evaluation intends to warrant the use of such simulation for further nested calculations on the smaller domain of the Iberian Peninsula (principal goal of the CALIOPE project). The results are evaluated statistically and dynamically, compared to performance goals and criteria, and to other model performances.

In this paper, Sect. 2 describes the models, the observational dataset and the statistical parameters calculated. Section 3 analyses the model results against available measurement data for the year 2004 and the modeled annual distribution of $\mathrm{O}_{3}, \mathrm{NO}_{2}, \mathrm{SO}_{2}, \mathrm{PM} 2.5$ and PM10. A thorough comparison with other European studies is presented in Sect. 4. Conclusions are drawn in Sect. 5.

\section{Methods}

\subsection{Model Description}

CALIOPE is a state-of-the-art modeling framework currently under further development. As shown in Fig. 1, CALIOPE-EU is a complex system that integrates a meteorological model (WRF-ARW), an emission processing model (HERMESEMEP), a mineral dust dynamic model (BSC-DREAM8b), and a chemical transport model (CMAQ) together in an air quality model system.

\subsubsection{Meteorology}

The Advanced Research Weather Research and Forecasting (WRF-ARW) Model v3.0.1.1 (Michalakes et al., 2004; Skamarock and Klemp, 2008) is used to provide the meteorology to the chemical transport model. WRF is a fully compressible, Eulerian non-hydrostatic model that solves the equations that govern the atmospheric motions. Microphysical processes are treated using the single-moment 3-class scheme as described in Hong et al. (2004). The sub-grid-scale effects of convective and shallow clouds are resolved by a modified version of the KainFritsch scheme based on Kain and Fritsch (1990) and Kain and Fritsch (1993). The surface layer scheme uses stability functions from Paulson (1970), Dyer and Hicks (1970), and Webb (1970) to compute surface exchange coefficients for heat, 


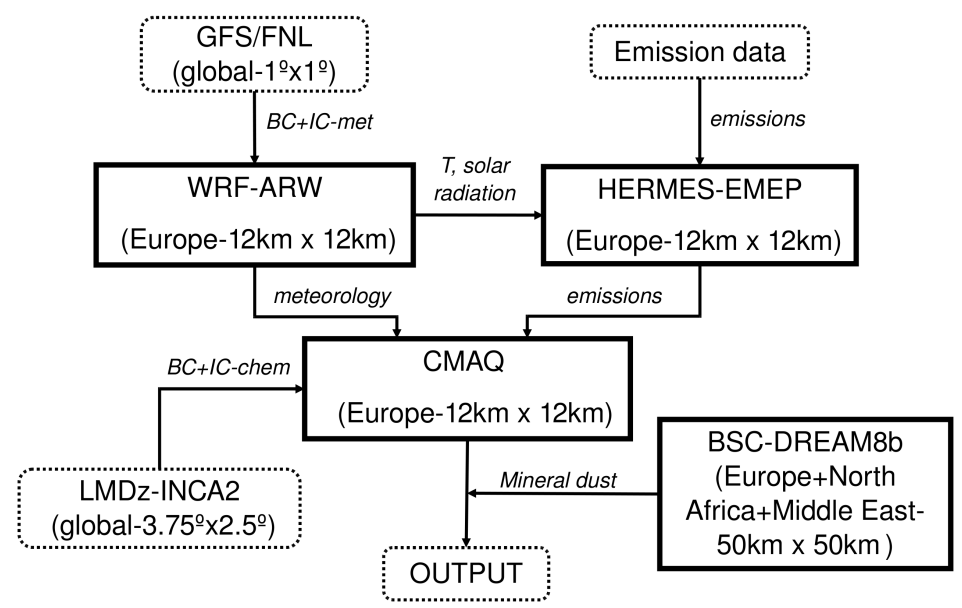

Figure 1: Modular structure of the CALIOPE-EU modeling system used to simulate air quality dynamics in Europe. Squared boxes with solid lines represent the main models of the framework. Boxes with dashed lines represent input/output dataset. Lines connecting boxes represent the information flow.

moisture, and momentum. The Noah Land-Surface scheme is used to provide heat and moisture fluxes over land points and sea-ice points. It is a 4-layer soil temperature and moisture model with canopy and snow cover prediction. The vertical sub-grid-scale fluxes caused by eddy transport in the atmospheric column are resolved by the Yonsei University planetary boundary layer (PBL) scheme (Noh et al., 2003). Finally, long-wave radiative processes are parameterized with the Rapid Radiative Transfer Model (Mlawer et al., 1997) while the short-wave radiative scheme is based on Dudhia (1989).

\subsubsection{Emissions}

The emission model is the High-Elective Resolution Modelling Emission System (HERMES, see Baldasano et al., 2008a). HERMES uses information and state-of-the-art methodologies for emission estimations. It calculates emissions by sector-specific sources or by individual installations and stacks. Raw emission data are processed by HERMES in order to provide a comprehensive description of the emissions to the air quality model. Emissions used for the European domain are derived from the 2004 annual EMEP emission database (EMEP, 2007). Disaggregation of EMEP (50 km resolution) data is performed in space (12 km $\times 12 \mathrm{~km})$ and time $(1 \mathrm{~h})$. The spatial and temporal top-down disaggregation is 
sector-dependent. A Geographical Information System (GIS) is used to remap the data to the finer grid applying different criteria through three datasets: a highresolution land use map (EEA, 2000), coordinates of industrial sites (European Pollutant Emission Register (EPER), Pulles et al., 2006), and vectorized road cartography of Europe (ESRI, 2003). In the vertical dimension, the sector dependent emission distribution for gases is applied following the EMEP model (widely used for regional air quality studies in Europe, Simpson et al., 2003). Distinct distributions are used for aerosols, leading in most cases to lower average emission heights than for gas phase emissions (De Meij et al., 2006; Pregger and Friedrich, 2009). In the time dimension, data are mapped from annual resolution to an hourly basis using the temporal factors of EMEP/MSC-W (Meteorological Synthesizing Centre-West).

\subsubsection{Chemistry}

The selected chemical transport model is the Models-3 Community Multiscale Air Quality Modeling System (Models-3/CMAQ, Byun and Ching, 1999; Binkowski, 1999; Byun and Schere, 2006). CMAQ is used to study the behavior of air pollutants from regional to local scales due to its generalized coordinate system and its advanced nesting grid capability. CMAQ version 4.5 , used in this study, has been extensively evaluated under various conditions and locations (Wyat Appel et al., 2007, 2008; Roy et al., 2007). Following the criteria of Jiménez et al. (2003) the Carbon Bond IV chemical mechanism is applied (CBM-IV, Gery et al., 1989). It includes aerosol and heterogeneous chemistry. The production of sea salt aerosol (SSA) is implemented as a function of wind speed and relative humidity (Gong, 2003; Zhang et al., 2005) through the AERO4 aerosol module. The AERO4 module distinguishes among different chemical aerosol components namely nitrate, sulfate, ammonium, elemental carbon, organic carbon with three subcomponents (primary, secondary anthropogenic and secondary biogenic), soil, sodium, and chlorine. Unspecified anthropogenic aerosols and aerosol water are additionally kept as separate components. Aerosols are represented by three size modes (Aitken, accumulation and coarse mode), each of them assumed to have a lognormal distribution (Binkowski and Roselle, 2003). Secondary inorganic aerosols (SIA) are generated by nucleation processes from their precursors to form nitrate ammonium and sulfate aerosols. Secondary organic aerosol (SOA) can be formed from aromatics (anthropogenic organic aerosols) and terpenes (biogenic organic aerosols, Schell et al., 2001). The aerosol microphysical description is based on a modal aerosol model (Binkowski and Roselle, 2003) using the ISORROPIA thermodynamic equilibrium model (Nenes et al., 1998). For a more com- 
plete description of the processes implemented in CMAQ, the reader is referred to Byun and Schere (2006).

\subsubsection{Mineral Dust}

The Dust REgional Atmospheric Model (BSC-DREAM8b) was designed to simulate and/or predict the atmospheric cycle of mineral dust (Nickovic et al., 2001; Pérez et al., 2006a,b). The simulations cover the Euro-Mediterranean and East-Asia areas. The aerosol description was improved from 4 to 8 bins to allow a finer description of dust aerosols. In this version dust-radiation interactions are included. The partial differential nonlinear equation for dust mass continuity is resolved in the Eulerian mode. BSC-DREAM8b is forced by the NCEP/Eta meteorological driver (Janjic, 1977, 1979, 1984, 1990, 1994). BSC-DREAM8b simulates the long-range transport of mineral dust at a $50 \mathrm{~km} \times 50 \mathrm{~km}$ resolution using 24 vertical layers extending up to $15 \mathrm{~km}$, every one hour. In this version dust-radiation interactions are included. An offline coupling is applied to the calculated concentrations of particulate matter from CMAQ (Jiménez-Guerrero et al., 2008).

\subsection{Model Setup}

The model system is initially run on a regional scale $(12 \mathrm{~km} \times 12 \mathrm{~km}$ in space and 1 hour in time) to model the European domain. WRF is configured with a grid of $479 \times 399$ points and $38 \sigma$ vertical levels ( 11 characterizing the PBL). The model top is defined at $50 \mathrm{hPa}$ to resolve properly the troposphere-stratosphere exchanges.

The simulation consists of 366 daily runs to simulate the entire year of 2004 . The choice for this specific year is based on the direct availability of the HERMESEMEP emission model for this year. The first 12 hours of each meteorological run are treated as cold start, and the next 23 hours are provided to the chemical transport model. The Final Analyses of the National Centers of Environmental Prediction (FNL/NCEP) at 12 hours UTC are used as initial conditions. The boundary conditions are provided at intervals of 6 hours. The FNL/NCEP data have a spatial resolution of $1^{\circ} \times 1^{\circ}$.

The CMAQ horizontal grid resolution corresponds to that of WRF. Its vertical structure was obtained by a collapse from the 38 WRF layers to a total of 15 layers steadily increasing from the surface up to $50 \mathrm{hPa}$ with a stronger concentration within the PBL.

Due to uncertain external influence, the definition of adequate lateral boundary conditions for gas phase chemistry in a regional model is a complex issue and 
an important source of errors. Variable intercontinental transport of pollutants substantially influences the levels of pollution in Europe (see, e.g., Li et al., 2002; Guerova et al., 2006). This air quality issue has been extensively studied. Recent works addressed the use of global chemical models to investigate the impact of chemical boundary conditions on regional scale $\mathrm{O}_{3}$ concentrations. Various studies were performed over the U.S. (Tang et al., 2007, 2008; Song et al., 2008; Reidmiller et al., 2009), whereas investigations over Europe remain scarce (Szopa et al., 2009). In a previous assessment of the model performances of CALIOPEEU (Jiménez-Guerrero et al., 2008), static chemical boundary conditions, adapted from Byun and Ching (1999), were used. In the present work, boundary conditions are based on the global climate chemistry model LMDz-INCA2 $(96 \times$ 72 grid cells, namely $3.75^{\circ} \times 2.5^{\circ}$ in longitude and latitude, with $19 \sigma$-p hybrid vertical levels, Szopa et al., 2009) developed by the Laboratoire des Sciences du Climat et l'Environnement (LSCE). Monthly mean data for the year 2004 are interpolated in the horizontal and vertical dimensions to force the major chemical concentrations at the boundaries of the domain (Piot et al., 2008). A detailed description of the INteractive Chemistry and Aerosol (INCA) model is presented in Hauglustaine et al. (2004) and Folberth et al. (2006).

\subsection{Air Quality Network}

Model output for gas and particulate phase concentrations are compared with ground-based measurements from the EMEP monitoring network for the year 2004. According to the criteria proposed by the European Environment Agency (EEA, Larssen et al., 1999), EMEP stations are located at a minimum distance of approximately $10 \mathrm{~km}$ from large emission sources. Consequently, all EMEP stations are assumed to be representative of regional background concentrations (Torseth and Hov, 2003). Therefore, the authors wish to stress that the model performances presented in this paper are evaluated only for background concentrations. The measurements are well documented and freely available on the EMEP web page (http://www.emep.int).

Before comparing the model results with EMEP data, the available measurements were filtered, and uncertain data (before and after a measurement interruption or a calibration of equipment) were removed. After this filtering, only observational sites with a temporal coverage greater than $85 \%$ were selected. Note that the final coverage of the dataset is rather disperse where France, Italy and southeastern Europe only include several stations. Measurement data used in this paper are given on a daily average. As a result, 60 stations were selected to evaluate $\mathrm{O}_{3}, 43$ for $\mathrm{NO}_{2}, 31$ for $\mathrm{SO}_{2}, 16$ for PM2.5 and 25 for PM10, respectively. The 


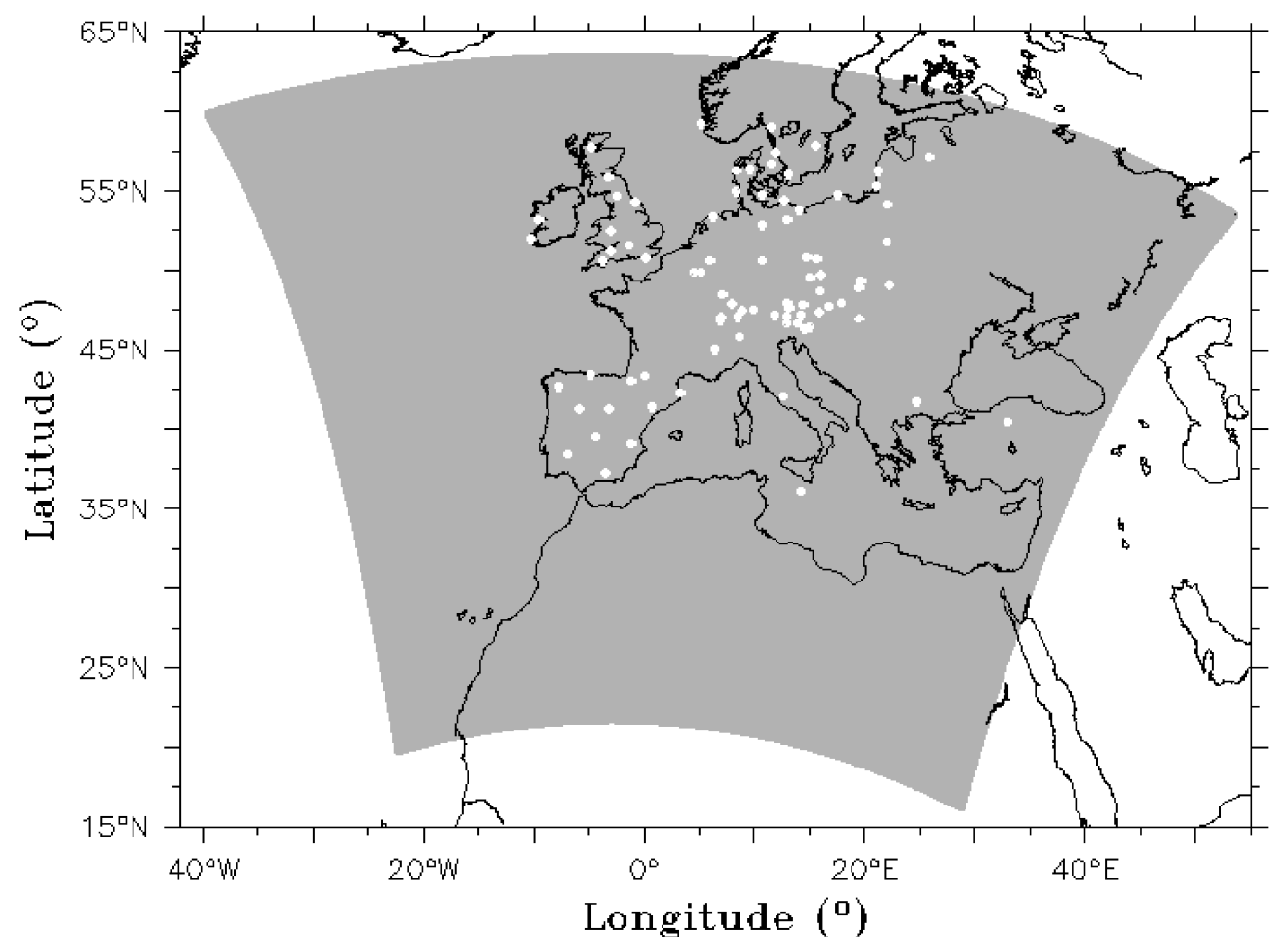

Figure 2: Grey shaded area: modeling domain used in this study. The white filled circles represent the selected subset of EMEP data collection sites. Characteristics of each station are listed in Table 1.

selected EMEP stations and measured pollutants that are used for this comparison are briefly described in Table 1 and their locations are displayed in Fig. 2.

As EMEP aerosol measurements supposedly remove all water content from samples to consider only dry aerosols, the simulated aerosol water was not taken into account in the model-to-data comparisons. However, as noted by Tsyro (2005), residual water persisting in sampled aerosols from EMEP may induce a substantial underprediction by the simulated dry aerosol concentrations. Moreover, although the aerodynamic diameter is used for PM10 and PM2.5 in measurement techniques, the model only considers the Stokes diameter to characterize the aerosol geometry. For more details on this issue, see Jiang et al. (2006). 
Table 1: Location and characteristics of selected EMEP stations for 2004 on a daily basis.

\begin{tabular}{|c|c|c|c|c|c|c|c|c|c|c|}
\hline & $\begin{array}{l}\text { Station } \\
\text { code }^{a}\end{array}$ & Latitude $^{b}$ & Longitude $^{b}$ & $\begin{array}{l}\text { Altitude } \\
(\mathrm{m})\end{array}$ & $\begin{array}{l}\text { Station } \\
\text { name }\end{array}$ & $\mathrm{O}_{3}$ & $\mathrm{NO}_{2}$ & $\mathrm{SO}_{2}$ & $\begin{array}{l}\text { Total } \\
\text { PM10 } \\
\end{array}$ & $\begin{array}{l}\text { Total } \\
\text { PM2.5 } \\
\end{array}$ \\
\hline 1 & AT02 & +47.767 & +16.767 & 117 & Illmitz & $\mathrm{x}^{c}$ & $\mathrm{x}$ & $\mathrm{x}^{c}$ & $\mathrm{x}$ & $\mathrm{x}$ \\
\hline 2 & AT04 & +47.650 & +13.200 & 851 & St. Koloman & & & $\mathrm{x}$ & & \\
\hline 3 & AT05 & +46.678 & +12.972 & 1020 & Vorhegg & $\mathrm{x}^{c}$ & & & & $\mathrm{x}$ \\
\hline 4 & AT30 & +48.721 & +15.942 & 315 & Pillersdorf bei Retz & $\mathrm{x}^{c}$ & & & & \\
\hline 5 & AT32 & +47.529 & +9.927 & 1020 & Sulzberg & $\mathrm{x}^{c}$ & & & & \\
\hline 6 & AT33 & +47.129 & +14.204 & 1302 & Stolzalpe bei Murau & $\mathrm{x}^{c}$ & & & & \\
\hline 7 & AT34 & +47.054 & +12.958 & 3106 & Sonnblick & $\mathrm{x}^{c}$ & & & & \\
\hline 8 & AT37 & +47.137 & +11.870 & 1970 & Zillertaler Alpen & $\mathrm{x}^{c}$ & & & & \\
\hline 9 & AT38 & +46.694 & +13.915 & 1895 & Gerlitzen & $\mathrm{x}^{c}$ & & & & \\
\hline 10 & AT40 & +47.348 & +15.882 & 1170 & Masenberg & $\mathrm{x}^{c}$ & & & & \\
\hline 11 & AT41 & +47.973 & +13.016 & 730 & Haunsberg & $\mathrm{x}^{c}$ & & & & \\
\hline 12 & AT48 & +47.833 & +14.433 & 899 & Zoebelboden & $\mathrm{x}^{c}$ & & & & \\
\hline 13 & BG53 & +41.700 & +24.733 & 1750 & Rojen peak & $\mathrm{x}^{c}$ & & & & \\
\hline 14 & $\mathrm{CH} 02$ & +46.817 & +6.950 & 510 & Payerne & & $\mathrm{x}$ & $\mathrm{x}$ & $\mathrm{x}$ & $\mathrm{x}$ \\
\hline 15 & $\mathrm{CH} 03$ & +47.483 & +8.900 & 540 & Tänikon & & $\mathrm{x}$ & & & $\mathrm{x}$ \\
\hline 16 & $\mathrm{CH} 04$ & +47.051 & +6.981 & 1130 & Chaumont & $\mathrm{x}^{c}$ & $\mathrm{x}$ & $\mathrm{x}$ & $\mathrm{x}$ & $\mathrm{x}$ \\
\hline 17 & CH05 & +47.069 & +8.466 & 1030 & Rigi & $\mathrm{x}^{c}$ & $\mathrm{x}$ & $\mathrm{x}$ & & $\mathrm{x}$ \\
\hline 18 & $\mathrm{CZ01}$ & +49.733 & +16.033 & 737 & Svratouch & $\mathrm{x}^{c}$ & $\mathrm{x}$ & $\mathrm{x}$ & & \\
\hline 19 & $\mathrm{CZO3}$ & +49.583 & +15.083 & 534 & Kosetice & $\mathrm{x}^{c}$ & $\mathrm{x}$ & $\mathrm{x}$ & & \\
\hline 20 & DE01 & +54.926 & +8.310 & 12 & Westerland & & & & & $\mathrm{x}$ \\
\hline 21 & DE02 & +52.800 & +10.750 & 74 & Langenbrgge & & $\mathrm{x}$ & $\mathrm{x}$ & $\mathrm{x}$ & $\mathrm{x}$ \\
\hline 22 & DE03 & +47.915 & +7.909 & 1205 & Schauinsland & $\mathrm{x}^{c}$ & & & $\mathrm{x}$ & $\mathrm{x}$ \\
\hline 23 & DE07 & +53.167 & +13.033 & 62 & Neuglobsow & & & & & $\mathrm{x}$ \\
\hline 24 & DE08 & +50.650 & +10.767 & 937 & Schmücke & & & & & $\mathrm{x}$ \\
\hline 25 & DE09 & +54.433 & +12.733 & 1 & Zingst & $\mathrm{x}^{c}$ & & & & $\mathrm{x}$ \\
\hline 26 & DE26 & +53.750 & +14.067 & 1 & Ueckermünde & $\mathrm{x}^{c}$ & & & & \\
\hline 27 & DE35 & +50.833 & +14.767 & 490 & Lückendorf & $\mathrm{x}^{c}$ & & & & \\
\hline 28 & DK03 & +56.350 & +9.600 & 13 & Tange & & & $\mathrm{x}$ & & \\
\hline 29 & DK05 & +54.733 & +10.733 & 10 & Keldsnor & & & & & $\mathrm{x}$ \\
\hline 30 & DK08 & +56.717 & +11.517 & 40 & Anholt & & $\mathrm{x}$ & $\mathrm{x}$ & & \\
\hline 31 & DK31 & +56.283 & +8.433 & 10 & Ulborg & $\mathrm{x}^{c}$ & & & & \\
\hline 32 & ES07 & +37.233 & -3.533 & 1265 & Víznar & $\mathrm{x}^{c}$ & $\mathrm{x}^{c}$ & & $\mathrm{x}$ & $\mathrm{x}$ \\
\hline 33 & ES08 & +43.442 & -4.850 & 134 & Niembro & $\mathrm{x}^{c}$ & $\mathrm{x}^{c}$ & $\mathrm{x}^{c}$ & $\mathrm{x}$ & $\mathrm{x}$ \\
\hline 34 & ES09 & +41.281 & -3.143 & 1360 & Campisábalos & $\mathrm{x}^{c}$ & $\mathbf{x}^{c}$ & $\mathrm{x}^{c}$ & $\mathrm{x}$ & $\mathrm{x}$ \\
\hline 35 & ES10 & +42.319 & +3.317 & 23 & Cabo de Creus & $\mathrm{x}^{c}$ & $\mathrm{x}^{c}$ & & $\mathrm{x}$ & $\mathrm{x}$ \\
\hline 36 & ES11 & +38.476 & -6.923 & 393 & Barcarrota & & $\mathbf{x}^{c}$ & $\mathrm{x}^{c}$ & $\mathrm{x}$ & $\mathrm{x}$ \\
\hline 37 & ES12 & +39.086 & -1.102 & 885 & Zarra & $\mathrm{x}^{c}$ & $\mathrm{x}^{c}$ & $\mathrm{x}^{c}$ & $\mathrm{x}$ & $\mathrm{x}$ \\
\hline 38 & ES13 & +41.283 & -5.867 & 985 & Penausende & $\mathrm{x}^{c}$ & $\mathbf{x}^{c}$ & $\mathrm{x}^{c}$ & $\mathrm{x}$ & $\mathrm{x}$ \\
\hline 39 & ES14 & +41.400 & +0.717 & 470 & Els Torms & $\mathrm{x}^{c}$ & $\mathrm{x}^{c}$ & $\mathrm{x}^{c}$ & $\mathrm{x}$ & $\mathrm{x}$ \\
\hline 40 & ES15 & +39.517 & -4.350 & 1241 & Risco Llano & $\mathrm{x}^{c}$ & $\mathrm{x}^{c}$ & $\mathrm{x}^{c}$ & $\mathrm{x}$ & $\mathrm{x}$ \\
\hline 41 & ES16 & +42.653 & -7.705 & 506 & O Saviñao & $\mathrm{x}^{c}$ & $\mathbf{x}^{c}$ & $\mathrm{x}^{c}$ & $\mathrm{x}$ & $\mathrm{x}$ \\
\hline 42 & FR08 & +48.500 & +7.133 & 775 & Donon & $\mathrm{x}^{c}$ & $\mathrm{x}^{c}$ & $\mathrm{x}$ & & \\
\hline 43 & FR09 & +49.900 & +4.633 & 390 & Revin & $\mathrm{x}^{c}$ & & $\mathrm{x}$ & & \\
\hline 44 & FR12 & +43.033 & -1.083 & 1300 & Iraty & $\mathrm{x}^{c}$ & & $\mathrm{x}$ & & \\
\hline 45 & FR13 & +43.375 & +0.104 & 236 & Peyrusse Vieille & $\mathrm{x}^{c}$ & $\mathrm{x}^{c}$ & $\mathrm{x}$ & & \\
\hline 46 & FR16 & +45.000 & +6.467 & 746 & Le Casset & $\mathrm{x}^{c}$ & & & & \\
\hline 47 & GB13 & +50.596 & -3.713 & 119 & Yarner Wood & $\mathrm{x}^{c}$ & & & & \\
\hline 48 & GB14 & +54.334 & -0.808 & 267 & High Muffles & $\mathrm{x}^{c}$ & & & & \\
\hline 49 & GB15 & +57.734 & -4.774 & 270 & Strath Vaich Dam & $\mathrm{x}^{c}$ & & & & \\
\hline 50 & GB31 & +52.504 & -3.033 & 370 & Aston Hill & $\mathrm{x}^{c}$ & & & & \\
\hline 51 & GB33 & +55.859 & -3.205 & 180 & Bush & $\mathrm{x}^{c}$ & & & & \\
\hline 52 & GB35 & +54.684 & -2.435 & 847 & Great Dun Fell & $\mathrm{x}^{c}$ & & & & \\
\hline 53 & GB36 & +51.573 & -1.317 & 137 & Harwell & $\mathrm{x}^{c}$ & $\mathbf{x}^{c}$ & & & \\
\hline 54 & GB37 & +53.399 & -1.753 & 420 & Ladybower Res. & $\mathrm{x}^{c}$ & $\mathrm{x}^{c}$ & & & \\
\hline
\end{tabular}


Table 2: Continued.

\begin{tabular}{|c|c|c|c|c|c|c|c|c|c|c|}
\hline & $\begin{array}{l}\text { Station } \\
\text { code }^{a}\end{array}$ & Latitude $^{b}$ & Longitude $^{b}$ & $\begin{array}{l}\text { Altitude } \\
\text { (m) }\end{array}$ & $\begin{array}{l}\text { Station } \\
\text { name }\end{array}$ & $\mathrm{O}_{3}$ & $\mathrm{NO}_{2}$ & $\mathrm{SO}_{2}$ & $\begin{array}{l}\text { Total } \\
\text { PM10 }\end{array}$ & $\begin{array}{l}\text { Total } \\
\text { PM2.5 }\end{array}$ \\
\hline 55 & GB38 & +50.793 & +0.179 & 120 & Lullington Heath & $\mathrm{x}^{c}$ & $\mathrm{x}^{c}$ & & & \\
\hline 56 & GB44 & +51.231 & -3.048 & 55 & Somerton & $\mathrm{x}^{c}$ & & & & \\
\hline 57 & HU02 & +46.967 & 19.583 & 125 & K-puszta & & $\mathrm{x}$ & & & \\
\hline 58 & IE01 & +51.940 & -10.244 & 11 & Valentina Observatory & $\mathrm{x}^{c}$ & $\mathrm{x}$ & & & \\
\hline 59 & IE31 & +53.167 & -9.500 & 15 & Mace Head & $\mathrm{x}^{c}$ & & & & \\
\hline 60 & IT01 & +42.100 & +12.633 & 48 & Montelibretti & & $\mathrm{x}$ & $\mathrm{x}$ & & $\mathrm{x}$ \\
\hline 61 & IT04 & +45.800 & +8.633 & 209 & Ispra & & $\mathrm{x}$ & & $\mathrm{x}$ & $\mathrm{x}$ \\
\hline 62 & LT15 & +55.350 & +21.067 & 5 & Preilla & $\mathrm{x}^{c}$ & $\mathrm{x}$ & $\mathrm{x}$ & & \\
\hline 63 & LV10 & +56.217 & +21.217 & 5 & Rucava & $\mathrm{x}^{c}$ & $\mathrm{x}$ & $\mathrm{x}$ & & \\
\hline 64 & LV16 & +57.133 & +25.917 & 183 & Zoseni & & $\mathrm{x}$ & $\mathrm{x}$ & & \\
\hline 65 & NL09 & +53.334 & +6.277 & 1 & Kullumerwaard & & $\mathrm{x}^{c}$ & & & \\
\hline 66 & MT01 & +36.100 & +14.200 & 160 & Giordan lighthouse & $\mathrm{x}^{c}$ & & & & \\
\hline 67 & NO43 & +59.000 & +11.533 & 160 & Prestebakke & $\mathrm{x}^{c}$ & & & & \\
\hline 68 & NO52 & +59.200 & +5.200 & 15 & Sandve & $\mathrm{x}^{c}$ & & & & \\
\hline 69 & PL02 & +51.817 & +21.983 & 180 & Jarczew & $\mathrm{x}^{c}$ & $\mathrm{x}$ & $\mathrm{x}$ & & \\
\hline 70 & PL03 & +50.733 & +15.733 & 1603 & Sniezka & $\mathrm{x}^{c}$ & $\mathrm{x}$ & $\mathrm{x}$ & & \\
\hline 71 & PL04 & +54.750 & +17.533 & 2 & Leba & $\mathrm{x}^{c}$ & $\mathrm{x}$ & $\mathrm{x}$ & & \\
\hline 72 & PL05 & +54.150 & +22.067 & 157 & Diabla Gora & & $\mathrm{x}$ & & & \\
\hline 73 & SE11 & +56.017 & +13.150 & 175 & Vavihill & $\mathrm{x}^{c}$ & $\mathrm{x}$ & $\mathrm{x}$ & & \\
\hline 74 & SE14 & +57.400 & +11.917 & 5 & $\mathrm{R} \dot{a} \mathrm{o}$ & $\mathrm{x}^{c}$ & $\mathrm{x}$ & & & \\
\hline 75 & SE32 & +57.817 & +15.567 & 261 & Norra-Kvill & $\mathrm{x}^{c}$ & & & & \\
\hline 76 & SI31 & +46.429 & +15.003 & 770 & Zarodnje & $\mathrm{x}^{c}$ & & & & \\
\hline 77 & SI32 & +46.299 & +14.539 & 1740 & Krvavec & $\mathrm{x}^{c}$ & & & & \\
\hline 78 & SK02 & +48.933 & +19.583 & 2008 & Chopok & & $\mathrm{x}$ & & & \\
\hline 79 & SK05 & +49.367 & +19.683 & 892 & Liesek & & $\mathrm{x}$ & & & \\
\hline 80 & SK06 & +49.050 & +22.267 & 345 & Starina & & $\mathrm{x}$ & $\mathrm{x}$ & & \\
\hline 81 & SK07 & +47.960 & +17.861 & 113 & Topolniky & & $\mathrm{x}$ & & & \\
\hline 82 & TR01 & +40.500 & +33.000 & 1169 & Cubuk II & & $\mathrm{x}$ & & & \\
\hline
\end{tabular}

${ }^{a}$ 2-letter country code plus 2-digit station code.

${ }^{b}$ A positive value indicates northern latitudes or eastern longitudes. A negative value indicates southern latitudes or western longitudes.

${ }^{c}$ Daily concentration calculated from hourly data. 


\subsection{Statistical Indicators}

There are a number of metrics that can be used to examine performances of air quality models (U.S. EPA, 1984, 1991; Cox and Tikvart, 1990; Weil et al., 1992; Chang and Hanna, 2004; Boylan and Russell, 2006). In particular, mean normalized bias error (MNBE) and mean normalized gross error (MNGE) normalizing the bias and error for each model-observed pair by the observation are useful parameters. Correlation coefficient (r), root mean square errors (RMSE) and mean bias (MB) values are also commonly used by the modeling community. For the evaluation of particulate matter concentrations, Boylan and Russell (2006) indicated that MNBE and MNGE may not be appropriate and suggested the mean fractional bias (MFB) and the mean fractional error (MFE) parameters instead.

The US-EPA suggested several performance criteria for simulated $\mathrm{O}_{3}$, such as MNBE $\leq \pm 15 \%$ and MNGE $\leq 35 \%$ (U.S. EPA, 1991, 2007) whereas the EC proposes a maximum uncertainty between measured and modeled concentrations of $50 \%$ and $30 \%$ for $\mathrm{O}_{3} / \mathrm{NO}_{2} / \mathrm{SO}_{2}$ daily mean and $\mathrm{NO}_{2} / \mathrm{SO}_{2}$ annual mean, respectively (European Commission, 2008). For particulate matter, Boylan and Russell (2006) proposed that the model performance goal be met when both the MFE and MFB are less than or equal to 50\% and $\pm 30 \%$, respectively, and the model performance criterion be met when both MFE $\leq 75 \%$ and MFB $\leq 60 \%$. All these criteria and goals are selected to provide metrics for the CALIOPE-EU model performances.

The model-to-data statistics MB, RMSE, MNBE, MNGE, MFB and MFE are selected for the present study, together with the measured and modeled mean and the correlation coefficient. Annual and seasonal mean statistics are computed, with seasons corresponding to winter (January, February and December), spring (March, April and May), summer (June, July and August) and fall (September, October and November).

It is important to note that, unless explicitly stated otherwise, the statistical norms are calculated without any minimum threshold when considering the measurement data. However, in the present work, statistics of annual means using thresholds are also computed. In that case we chose $80 \mu \mathrm{g} \mathrm{m}^{-3}$ for $\mathrm{O}_{3}$ (according to recommendations of the US-EPA, U.S. EPA, 1991; Russell and Dennis, 2000), $1.5 \mu \mathrm{g} \mathrm{m}^{-3}$ for $\mathrm{NO}_{2}, 0.2 \mu \mathrm{g} \mathrm{m}^{-3}$ for $\mathrm{SO}_{2}, 1.5 \mu \mathrm{g} \mathrm{m}^{-3}$ for PM10 and $3.5 \mu \mathrm{g} \mathrm{m}^{-3}$ for PM2.5, respectively. 


\section{Results and Discussion}

As CALIOPE-EU is a fundamental model system the authors wish to stress that, apart from the discussion of the Fig. 6 and its related statistics (Table 4), neither correction factors nor any adjusting model parameterization were applied to the model output or the original model codes. First, in Sect. 3.1, a thorough model evaluation is performed through statistical and dynamical performances. Later, in Sect. 3.2, a general description of the annual mean distribution of each pollutant is provided to determine each pattern throughout Europe.

\subsection{Model evaluation}

Fig. 3 represents (left) the temporal series of the model (black lines) and daily measured EMEP data (grey lines) as an average of all the stations for each pollutant over the complete year 2004, together with (right) the scatterplot of the modeled-measured daily data. Table 3 shows annual and seasonal statistics calculated at the location of all EMEP stations. Statistics are calculated for daily averages of $\mathrm{O}_{3}, \mathrm{NO}_{2}, \mathrm{SO}_{2}, \mathrm{PM} 2.5$ and PM10. In the case of $\mathrm{O}_{3}$, the daily peak of hourly mean $\mathrm{O}_{3}$ is also computed as it is one of the most important parameters to be considered.

\subsubsection{Ozone}

A total of 60 EMEP stations constitute the $\mathrm{O}_{3}$ measurement dataset to be compared to the simulation (see Table 1). In Fig. 3a, the time series of both simulated and observed $\mathrm{O}_{3}$ concentrations are presented. The annual trend is well captured with an annual correlation of daily mean and daily peak concentrations of 0.66 and 0.69 , respectively (see Table 3). Although the annual daily mean bias is null, the inter-annual variability leads to an annual RMSE of up to $20.6 \mu \mathrm{g} \mathrm{m}^{-3}$. Annual and seasonal MNBE and MNGE values for daily mean and daily maximum concentrations show relatively good performances which are in accordance with the recommendations of the EC and the US-EPA (see Sect. 2.4).

Results show distinct inter-seasonal behaviors between colder and warmer months. From January to March and from October to December, the model tends to underestimate the mean concentrations (in winter, $\mathrm{MB}=-5.8 \mu \mathrm{g} \mathrm{m}^{-3}$ ), while it slightly overestimates concentrations in summer months $\left(\mathrm{MB}=7.5 \mu \mathrm{g} \mathrm{m}^{-3}\right.$ ). Correlation values are lowest for both daily mean and daily peak correlations in the winter ( $\mathrm{r}=0.54$ and 0.50 , respectively). This inter-seasonal variability is attributed to the model sensitivity to boundary conditions near the surface in winter. During decreases of photochemical reactions in fall and winter the concentrations 
Table 3: Seasonal and annual statistics obtained with CALIOPE-EU over Europe for 2004 at the EMEP stations. Winter: January, February and December; Spring: March, April, May; Summer: June, July, August; Fall: September, October, November. The number of data points indicates the number of pair measurement-model used to compute the statistics. The calculated statistics are: measured mean for available data $\left(\mu \mathrm{g} \mathrm{m}^{-3}\right)$, modeled mean for the whole year $\left(\mu \mathrm{g} \mathrm{m}^{-3}\right)$, correlation (r), Mean Bias (MB, $\mu \mathrm{g} \mathrm{m}^{-3}$ ), Root Mean Square Error (RMSE, $\mu \mathrm{g} \mathrm{m}^{-3}$ ), Mean Normalized Bias Error (MNBE, \%), Mean Normalized Gross Error (MNGE, \%), Mean Fractional Bias (MFB, $\%$ ) and Mean Fractional Error (MFE, \%). For the annual mean calculated with threshold, we used $80 \mu \mathrm{g} \mathrm{m}^{-3}$ for $\mathrm{O}_{3}, 1.5 \mu \mathrm{g} \mathrm{m}^{-3}$ for $\mathrm{NO}_{2}, 0.2 \mu \mathrm{g} \mathrm{m}^{-3}$ for $\mathrm{SO}_{2}, 1.5 \mu \mathrm{g} \mathrm{m}^{-3}$ for PM2.5 and $3.5 \mu \mathrm{g}$ $\mathrm{m}^{-3}$ for PM10, respectively. Seasonal statistics are computed without threshold.

\begin{tabular}{|c|c|c|c|c|c|c|c|c|c|c|c|}
\hline & Period & $\begin{array}{c}\text { Data } \\
\text { points }\end{array}$ & $\begin{array}{c}\text { Measured } \\
\text { mean }\end{array}$ & $\begin{array}{c}\text { Modeled } \\
\text { mean }\end{array}$ & $\mathrm{r}$ & MB & RMSE & MNBE & MNGE & MFB & MFE \\
\hline \multirow{6}{*}{$\begin{array}{c}\mathrm{O}_{3} \text { daily } \\
\text { (60 stations) }\end{array}$} & Winter & 5257 & 60.8 & 54.8 & 0.54 & -5.8 & 21.4 & -1 & 34 & -11 & 32 \\
\hline & Spring & 5466 & 84.5 & 82.6 & 0.55 & -1.8 & 20.8 & 0 & 21 & -4 & 22 \\
\hline & Summer & 5443 & 79.5 & 86.9 & 0.64 & 7.5 & 19.8 & 15 & 23 & 11 & 20 \\
\hline & Fall & 5197 & 60.7 & 60.1 & 0.58 & -0.3 & 20.3 & 9 & 34 & -1 & 30 \\
\hline & Annual (no threshold) & 21363 & 71.6 & 71.2 & 0.66 & 0.0 & 20.6 & 6 & 28 & -1 & 26 \\
\hline & Annual (threshold) & 7299 & 96.9 & 91.1 & 0.44 & -5.9 & 20.5 & -6 & 17 & -8 & 19 \\
\hline \multirow{6}{*}{$\begin{array}{l}\mathrm{O}_{3} \text { daily peak } \\
\text { (60 stations) }\end{array}$} & Winter & 5257 & 73.7 & 67.3 & 0.50 & -6.2 & 24.1 & -5 & 28 & -12 & 29 \\
\hline & Spring & 5466 & 101.9 & 97.3 & 0.55 & -4.5 & 21.5 & -4 & 18 & -6 & 19 \\
\hline & Summer & 5443 & 101.1 & 100.5 & 0.65 & -0.5 & 20.2 & 3 & 16 & 1 & 16 \\
\hline & Fall & 5197 & 77.2 & 70.2 & 0.65 & -6.6 & 21.2 & -6 & 25 & -11 & 26 \\
\hline & Annual (no threshold) & 21363 & 88.7 & 83.9 & 0.69 & -4.4 & 21.8 & -3 & 22 & -7 & 22 \\
\hline & Annual (threshold) & 12891 & 104.2 & 97.5 & 0.54 & -6.7 & 22.4 & -6 & 18 & -9 & 19 \\
\hline \multirow{6}{*}{$\begin{array}{l}\mathrm{NO}_{2} \text { daily } \\
\text { (43 stations) }\end{array}$} & Winter & 3600 & 12.1 & 8.0 & 0.67 & -4.2 & 12.7 & 3 & 57 & -21 & 55 \\
\hline & Spring & 3787 & 9.4 & 4.8 & 0.66 & -4.5 & 10.6 & -27 & 53 & -51 & 67 \\
\hline & Summer & 3843 & 6.2 & 3.5 & 0.59 & -2.7 & 5.7 & -29 & 54 & -53 & 69 \\
\hline & Fall & 3725 & 9.4 & 6.0 & 0.66 & -3.4 & 10.1 & -15 & 48 & -34 & 56 \\
\hline & Annual (no threshold) & 15035 & 9.3 & 5.6 & 0.67 & -3.7 & 10.1 & -17 & 53 & -40 & 62 \\
\hline & Annual (threshold) & 14138 & 9.8 & 5.8 & 0.66 & -4.0 & 10.4 & -20 & 51 & -42 & 61 \\
\hline \multirow{6}{*}{$\begin{array}{l}\mathrm{SO}_{2} \text { daily } \\
\text { (31 stations) }\end{array}$} & Winter & 2629 & 2.2 & 2.6 & 0.62 & 0.5 & 2.9 & 80 & 122 & 8 & 70 \\
\hline & Spring & 2749 & 1.6 & 2.0 & 0.63 & 0.4 & 1.9 & 62 & 96 & 13 & 62 \\
\hline & Summer & 2707 & 1.2 & 1.6 & 0.49 & 0.4 & 1.8 & 86 & 121 & 14 & 65 \\
\hline & Fall & 2604 & 1.4 & 2.0 & 0.56 & 0.7 & 2.3 & 105 & 134 & 25 & 68 \\
\hline & Annual (no threshold) & 10689 & 1.6 & 2.1 & 0.60 & 0.5 & 2.2 & 83 & 118 & 15 & 66 \\
\hline & Annual (threshold) & 10384 & 1.7 & 2.2 & 0.60 & 0.5 & 2.3 & 72 & 108 & 13 & 65 \\
\hline \multirow{6}{*}{$\begin{array}{l}\text { PM2.5 daily } \\
\text { (16 stations) }\end{array}$} & Winter & 1171 & 13.7 & 4.8 & 0.62 & -8.4 & 15.3 & -47 & 59 & -78 & 86 \\
\hline & Spring & 1264 & 12.2 & 5.2 & 0.50 & -6.7 & 10.6 & -50 & 59 & -79 & 84 \\
\hline & Summer & 1396 & 12.2 & 6.8 & 0.49 & -5.4 & 9.1 & -45 & 56 & -71 & 78 \\
\hline & Fall & 1287 & 11.5 & 6.2 & 0.52 & -5.0 & 9.3 & -39 & 53 & -62 & 72 \\
\hline & Annual (no threshold) & 5118 & 12.3 & 5.7 & 0.47 & -6.3 & 11.2 & -45 & 56 & -72 & 80 \\
\hline & Annual (threshold) & 4756 & 13.0 & 6.3 & 0.45 & -6.7 & 11.6 & -46 & 57 & -74 & 81 \\
\hline \multirow{6}{*}{$\begin{array}{l}\text { PM10 daily } \\
\text { (25 stations) }\end{array}$} & Winter & 1994 & 18.0 & 6.6 & 0.54 & -11.2 & 18.2 & -47 & 60 & -78 & 86 \\
\hline & Spring & 2087 & 17.7 & 7.1 & 0.54 & -10.5 & 15.0 & -54 & 59 & -84 & 87 \\
\hline & Summer & 2204 & 18.5 & 8.2 & 0.60 & -10.5 & 16.1 & -54 & 58 & -83 & 86 \\
\hline & Fall & 2104 & 17.0 & 8.1 & 0.62 & -9.0 & 13.5 & -44 & 55 & -70 & 77 \\
\hline & Annual (no threshold) & 8389 & 17.8 & 7.5 & 0.57 & -10.3 & 15.8 & -50 & 58 & -79 & 84 \\
\hline & Annual (threshold) & 7918 & 18.7 & 7.8 & 0.55 & -10.9 & 16.2 & -53 & 57 & -82 & 85 \\
\hline
\end{tabular}


defined at the boundaries proportionally acquire an increasing role in the control of the concentration levels simulated within the domain. Also, the large concentrations of $\mathrm{O}_{3}$ in the highest layers of the boundary profile (reaching the stratosphere) was found to be responsible for episodic inaccurate stratosphere-troposphere exchanges during colder months (not shown here; also see Eisele et al., 1999; Cristofanelli and Bonasoni, 2009). Such finding was highlighted very recently by Lam and $\mathrm{Fu}$ (2009) who pointed the inaccurate treatment of the tropopause in CMAQ as the issue causing such artifact. On the other hand, the mean biases for daily and daily peak concentrations are positive during warmer months with lowest RMSE values (19.8 and $20.2 \mu \mathrm{g} \mathrm{m}^{-3}$ in summer, respectively). Model-observations correlations, MNBE and MNGE values also reach the best values during this period. This performance demonstrates the greater ability of the model to accurately simulate ozone during its intense photochemical formation in warmer months. Daily variations are satisfactorily reproduced (see scatter plot in Fig. 3b with nearly $95 \%$ of the data points falling within the 1:2 and 2:1 factor range). However, due to uncertainties in the modeled nocturnal $\mathrm{NO}_{\mathrm{x}}$ cycle, the $\mathrm{O}_{3}$ chemistry at night tends to overpredict the observed concentrations. Such behaviour is partly reflected by the difference between the annual mean biases calculated with or without the minimum threshold of $80 \mu \mathrm{g} \mathrm{m}^{-3}$ on the measured data. By implementing this threshold a part of overestimated nocturnal measured values is not considered which induces a negative value of $-5.9 \mu \mathrm{g} \mathrm{m}^{-3}$ compared to 0.0 using no threshold. For extreme values (above $150 \mu \mathrm{g} \mathrm{m}^{-3}$ ) the observed concentrations are systematically underestimated by the model (see Fig. 3b). This behavior is most likely caused by high local pollution transported to rural sites but not captured with the current horizontal resolution of the model (see Ching et al., 2006).

Fig. 4 and Fig. 5 present the spatial distributions in winter (left) and summer (right) of the correlation and mean bias, respectively, without threshold on measurements. In the case of $\mathrm{O}_{3}$ two different spatial regimes can be distinguished: seasonal correlations are highest in England, central and southern Europe, while Ireland and the countries along the North and Baltic Seas present lower performances. We attribute these lower performances of the model at these locations mostly to their relative proximity with the northern boundary of the domain. The most remote sites with low levels of $\mathrm{O}_{3}$ display the lowest seasonal correlations (see Irish and northern stations; from -0.2 to 0.2 in winter, from 0 to 0.4 in summer). The model skills improve notably from winter to summer as a result of the increasing importance of the photochemical production of ozone. In summer most of the seasonal correlations are comprised between 0.4 and 0.9. Also, statistics are surprisingly satisfactory in complex regions such as the Alpine (stations $\mathrm{CHO} 2$ to 
CH05 and FR16) or the Pyrenean chains (FR12). As mentioned above in this section the model tends to underestimate the mean concentrations in winter and overestimate in summer (Fig. 5). It is noted that mean biases in southern Europe have an inter-seasonal variability less pronounced than in the rest of Europe with values rather positive. In summer, the lowest $\mathrm{MB}$ values are found in regions of low mean $\mathrm{O}_{3}$ levels such as the Alpine chain, Ireland and some Spanish stations.

\subsubsection{Nitrogen Dioxide}

As shown in Table 1, 43 stations were used to provide $\mathrm{NO}_{2}$ measurements throughout Europe. The temporal and spatial variability of the simulated $\mathrm{NO}_{2}$ in Europe is larger than for $\mathrm{O}_{3}$, reflecting its higher sensitivity to meteorology and model resolution (Vautard et al., 2009). The model-observations comparison, presented in Fig. 3c and Fig. 3d highlights a correct annual trend, but with a systematic negative bias throughout the year. The dynamics is often well captured but the amplitude of daily variations is underestimated. These low variations have a direct impact on the daily variations of ozone in the PBL.

The annual average correlation is high $(\mathrm{r}=0.67$, see Table 3$)$, with better performances in winter than in summer. Chemical processes, less dominant compared to transport in winter, could explain such differences (Bessagnet et al., 2004). Annual and seasonal mean biases are relatively high, ranging from -4.5 to $-2.7 \mu \mathrm{g} \mathrm{m}^{-3}$, leading to mean normalized error values rather near the maximum uncertainty proposed by the EC. High measured concentrations (above 70 $\mu \mathrm{g} \mathrm{m}^{-3}$ ) are particularly underestimated (see Fig. 3d). When comparing modeled results versus measured data, $59.1 \%$ of the corresponding data pairs fall within a factor of 2 of each other, and $92.9 \%$ within a factor of 5.

The statistics of the model are spatially displayed in Fig. 4 and Fig. 5. $\mathrm{NO}_{2}$ concentrations are mostly driven by local to regional emissions. Therefore, remote and clean boundary conditions are not significant contributors to the simulated concentrations of $\mathrm{NO}_{2}$ in Europe. Correlations are highest in winter for the areas including UK, northern countries and some spanish stations. In these regions emissions of $\mathrm{NO}_{\mathrm{x}}$ are generally either high or very low (also see Sect. 3.2.2). Low correlations are mainly concentrated in central Europe (coefficients between -0.2 and 0.4 ). Numerous stations located in low- $\mathrm{NO}_{2}$ areas display satisfactory seasonal mean biases (see northern and central Europe and Spain with seasonal $\mathrm{MB}= \pm 2 \mu \mathrm{g} \mathrm{m}^{-3}$ ), while stations substantially affected by transport from source regions display the highest seasonal mean biases (Fig. 5). The aforementioned large underestimations of high measured concentrations are mainly caused by the three stations from Great Britain (GB36, GB37 and GB38, see Table 1). These 
stations frequently undergo high pollution events caused by emissions from road traffic and combustion processes. To a lesser extent, these highly polluted plumes from the United Kingdom (UK) also affect the measuring station in The Netherlands (NL09) under westerly winds and contribute to the increase in mean bias values when the transport is not accurately simulated. At these locations, negative mean biases reaching up to $22 \mu \mathrm{g} \mathrm{m}^{-3}$ on annual average are noted with highest biases in winter. Such differences are most likely caused by the underestimation of emission sources in these areas. Altogether, the analysis of the spatial distribution of the model skills shows that the level $\mathrm{NO}_{2}$ concentrations at very rural stations is well captured but with low correlation coefficients, while mean biases and correlation coefficients are greatest at polluted stations.

Apart from sources unaccounted for in the emission database, uncertainties may also arise in the spatial and temporal distribution of the sources (Stern et al., 2008). In the $\mathrm{PBL} \mathrm{NO}_{\mathrm{x}}$ concentrations are dominated by emissions near the surface, such as traffic and domestic heating, which are subject to strong spatial and temporal variations.

\subsubsection{Sulfur Dioxide}

For $\mathrm{SO}_{2}$, the model results were evaluated against 31 EMEP stations measuring daily mean concentrations of $\mathrm{SO}_{2}$ at background sites. The stations are located across the Iberian Peninsula, central and north-eastern Europe. It is worth noting that the daily mean concentrations are low and provide information about the background levels of $\mathrm{SO}_{2}$ across Europe only. Fig. 3e shows the time series of the daily mean concentrations of $\mathrm{SO}_{2}$ at the EMEP stations together with the model simulation at these stations. Results show that $\mathrm{SO}_{2}$ concentrations are well captured by the model, although some observed peaks are overestimated. During the cold months (January, February, March, October, November) the model agrees well with observations, and monthly variations of $\mathrm{SO}_{2}$ are well captured. On the other hand, during the warm period (April, May, June, July, August and September) results present an overall positive bias of $1 \mu \mathrm{g} \mathrm{m}^{-3}$. September and December months are characterized by some episodes of large overestimations. Overall, the dynamical evolution of the model is in good agreement with the observations. For instance, January undergoes two major episodes of enhanced $\mathrm{SO}_{2}$ that the model reproduces well. Although there is a clear overestimation during some periods, the model is able to reproduce the variations of the daily mean concentrations.

As regard to the scatter plot (Fig. 3f), 54.3\% of the model results match with observations within a factor of 2 , and $90.1 \%$ within a factor of 5 . The model results match the main tendency of the daily observations with an annual correlation 
factor $r=0.60$.

The annual mean MNGE and MNBE values reach up to $118 \%$ and $83 \%$ respectively (Table 3). Such rather high normalized errors are usual when evaluating background stations that measure very low values of $\mathrm{SO}_{2}$. The annual RMSE is $2.2 \mu \mathrm{g} \mathrm{m}^{-3}$, much lower than for the other pollutants analyzed in the present work. The seasonal statistics show better results for spring, with mean MNGE value of $96 \%$. The MNBE values increase for summer and fall as the daily mean observations remain below $2 \mu \mathrm{g} \mathrm{m}^{-3}$.

The spatial distribution of the correlation coefficient $r$ shows a large variability per station. For instance, during winter while some northern stations have high correlations $(0.6<\mathrm{r}<0.9)$, various low correlations are observed in central and southern Europe. During summertime the correlation improves in stations located over central Europe. In Spain, the model performs relatively homogeneously across the year, with a variation of the correlation between summer and winter less pronounced than in central Europe. However, the correlation per station in Spain is slightly lower than in the rest of Europe, especially during summer.

Considering the mean bias for winter and summer (Fig. 5), results show a low bias across all stations. Only one station located in eastern Poland displays a high positive bias ( $>5 \mu \mathrm{g} \mathrm{m}^{-3}$ in summer). This station may largely contribute to the seasonal and annual average positive bias mentioned in Table 3 . The uncertainties of the emission inventory in eastern Europe may be associated to the higher bias observed in some stations of Poland and the Czech Republic, especially in winter. Also, the top-down disaggregation from 50 to $12 \mathrm{~km}$ is a source of uncertainties to be considered.

\subsubsection{Particulate matter}

A total of 16 and 25 stations are used to evaluate the simulated PM2.5 and PM10 concentrations, respectively. Although the model presents a clear systematic negative bias, it has noticeable capabilities to reproduce the dynamics of PM2.5 for the whole year (Fig. 3g). The modeling system simulates the most important PM2.5 episodes across the whole year. The correlation coefficients for winter and fall seasons are 0.62 and 0.52 , respectively, and 0.50 and 0.49 for spring and summer (Table 3). The MFE and MFB for PM2.5 do not fall within the performance criteria or performance goal proposed by Boylan and Russell (2006).

In order to evaluate the annual variability of PM in comparison to measurement data, Fig. 6 displays the annual time series of PM2.5 and PM10 multiplied by a correction factor of 2 . Such correction is not meant to modify the statistics but rather to evaluate the annual dynamics of the model and approximate the un- 
Table 4: Seasonal and annual statistics obtained with CALIOPE-EU over Europe for 2004 (see Table 3). For quantification purposes, the simulated concentrations of PM are multiplied by a correction factor of 2 at the EMEP stations.

\begin{tabular}{|c|c|c|c|c|c|c|c|c|c|c|c|}
\hline & Period & $\begin{array}{l}\text { Data } \\
\text { points }\end{array}$ & $\begin{array}{c}\text { Measured } \\
\text { mean }\end{array}$ & $\begin{array}{l}\text { Modeled } \\
\text { mean }\end{array}$ & $\mathrm{r}$ & MB & RMSE & MNBE & MNGE & MFB & MFE \\
\hline \multirow{6}{*}{$\begin{array}{l}\text { PM2.5 daily } \\
\text { adapted }(\times 2) \\
(16 \text { stations })\end{array}$} & Winter & 1171 & 13.7 & 9.6 & 0.62 & -3.3 & 12.4 & 6 & 60 & -20 & 58 \\
\hline & Spring & 1264 & 12.2 & 10.4 & 0.50 & -1.3 & 10.0 & 1 & 49 & -19 & 47 \\
\hline & Summer & 1396 & 12.2 & 13.6 & 0.49 & 1.3 & 13.0 & 10 & 52 & -10 & 45 \\
\hline & Fall & 1287 & 11.5 & 12.3 & 0.52 & 1.5 & 11.4 & 22 & 58 & -1 & 47 \\
\hline & Annual (no threshold) & 5118 & 12.3 & 11.5 & 0.47 & -0.3 & 11.8 & 10 & 54 & -12 & 49 \\
\hline & Annual (threshold) & 4756 & 13.0 & 12.6 & 0.45 & -0.4 & 12.2 & 7 & 53 & -14 & 49 \\
\hline \multirow{6}{*}{$\begin{array}{l}\text { PM10 daily } \\
\text { adapted }(\times 2) \\
(25 \text { stations })\end{array}$} & Winter & 1994 & 18.0 & 13.3 & 0.54 & -4.3 & 14.7 & 6 & 61 & -21 & 57 \\
\hline & Spring & 2087 & 17.7 & 14.2 & 0.54 & -3.4 & 12.4 & -7 & 46 & -25 & 48 \\
\hline & Summer & 2204 & 18.5 & 16.3 & 0.60 & -2.4 & 14.8 & -7 & 46 & -23 & 49 \\
\hline & Fall & 2104 & 17.0 & 16.1 & 0.62 & -0.9 & 12.1 & 13 & 56 & -10 & 49 \\
\hline & Annual (no threshold) & 8389 & 17.8 & 15.0 & 0.57 & -2.7 & 13.6 & 1 & 52 & -20 & 51 \\
\hline & Annual (threshold) & 7918 & 18.7 & 15.6 & 0.55 & -3.1 & 13.9 & -5 & 48 & -23 & 50 \\
\hline
\end{tabular}

derestimation of PM mass. By multiplying the model results by such a factor, the results of the model system are in very good agreement with observations. The model is able to reproduce the daily evolution of PM2.5 across the year. Nevertheless, the model tends to underestimate the peaks during wintertime, while during summertime the model overestimates some episodes. By calculating the annual MFE and MFB with the adapted model output, the results now fall within the performance goal recommended by Boylan and Russell (2006) with a MFE $=49 \%$ and $\mathrm{MFB}=-12 \%$ (Table 4). It is important to note that the statistics are biased towards measurements obtained in Spain, since 10 out of 16 EMEP stations are located there (Fig. 4 and Fig. 5). Overall, the MFB and MFE are homogeneous at most stations (not shown).

For PM10, annual correlations are higher than for PM2.5 (annual mean correlation $\mathrm{r}=0.57$ ). The model is able to reproduce most of the particulate matter events, although the model hardly reproduces the amplitude of the events and presents a systematic underestimation. Concerning the variability of the results (Fig. 3j), 69.4\% of the data match with observations within a factor 2, and 96.6\% within a factor 5. As for PM2.5, PM10 results present a very good agreement with the observations if a factor of 2 is applied to the results (Fig. 6b). The adapted results for PM10 match consistently with the observations except for the Saharan dust outbreak event on July $24-26^{\text {th }}$ which affected southern, central and eastern 
Spain but was not captured by BSC-DREAM8b.

The annual mean MFB and MFE of the adapted results amount to $-20 \%$ and $51 \%$, respectively (Table 4). These results are in accordance with the recommendations for particulate matter mentioned in Sect. 2.4 and fall within the performance criteria of Boylan and Russell (2006). The spatial distribution of the correlation coefficient and the mean bias for winter and summer point out that the model performs better in southern than in northern Europe, for PM10 (Fig. 4 and Fig. 5). Stations located between the Baltic and the North Sea (DE01, DE09, DK05; see Table 1) display weak seasonal correlation coefficient $(-0.1<\mathrm{r}<0.3)$. However, continental stations of central Europe (Germany, Switzerland and Austria) mainly affected by anthropogenic emissions present good performances for PM10. Correlations are in the range of 0.3-0.7 during winter and improves in summer. From all coastal sites affected by SSA, the stations in Spain display the highest correlations (Niembro and Cabo de Creus with $0.4<\mathrm{r}<0.6$ ). At the south European stations affected by Saharan dust outbreaks, namely Spain and Italy, correlations are high across the year $(0.5<\mathrm{r}<0.9$, except ES13). The inclusion of BSC-DREAM8b model results largely contributes to the improvement of the model performances at such southern stations as previously noted by Jiménez-Guerrero et al. (2008).

Many studies have recognized the difficulty of models to simulate the mass of particulate matter over Europe (van Loon et al., 2004; Matthias, 2008). The underestimation of total particulate mass is, among others, the result from the lack of fugitive dust emissions, resuspended matter (Vautard et al., 2005a), a possible underestimation of primary carbonaceous particles (Schaap et al., 2004; Tsyro, 2005), the inaccuracy of SOA formation (Simpson et al., 2007), the difficulty of representing primary PM emission from wood burning and other sources (Tsyro et al., 2007) and a more general lack of process knowledge (Stern et al., 2008). While multiplying the model results of CALIOPE-EU by a factor of 2, it was shown that the dynamics of particulate matter (both PM2.5 and PM10) can be well captured. Using such methodology the levels generally simulated by CALIOPEEU were quantified to be approximately half of the observed values.

\subsection{Pattern Description}

In the following section, it is important to note that the description of the simulated chemical patterns does not take into account the model-observations discrepancies highlighted in Sect. 3.1. 


\subsubsection{Ozone}

Modeled $\mathrm{O}_{3}$ average concentrations over Europe (Fig. 7a) show an increasing gradient from the northern and western boundaries to the more continental and Mediterranean areas, resulting from large variations in climate patterns (Beck and Grennfeld, 1993; Lelieveld et al., 2002; EEA, 2005; Jiménez et al., 2006). In the troposphere $\mathrm{O}_{3}$ has a residence time of several days to a week which permits its transport on regional scales (Seinfeld and Pandis, 1998). The highest concentrations are found in the Mediterranean basin and southern Europe (nearly 90-105 $\mu \mathrm{g}$ $\mathrm{m}^{-3}$ ), as this region is particularly affected by intense photochemical production of $\mathrm{O}_{3}$ (EEA, 2005; Vautard et al., 2005b). Detailed descriptions of ozone formation and transport over the Mediterranean area can be found in Gerasopoulos et al. (2005) or Cristofanelli and Bonasoni (2009). Other important factor for the land-sea difference is the slow dry deposition of $\mathrm{O}_{3}$ on water and also the low photochemical formation due to the low precursors concentration (Wesely and Hicks, 2000). In central and eastern Europe, simulated annual $\mathrm{O}_{3}$ concentrations range from 70 to $85 \mu \mathrm{g} \mathrm{m}^{-3}$, with a slight west-to-east gradual build-up caused by the association of precursor emissions and predominant westerly winds. Northwestern areas show rather low concentrations of $\mathrm{O}_{3}\left(60-67 \mu \mathrm{g} \mathrm{m}^{-3}\right)$ due to reduced solar radiation and the influence of the clean marine air. Due to higher $\mathrm{O}_{3}$ concentrations in elevated terrains, the major mountainous regions such as the Alpine and Pyrennean chains as well as the Carpathian mountains (mainly in Rumania) display mean $\mathrm{O}_{3}$ concentrations in the range of $85-95 \mu \mathrm{g} \mathrm{m}^{-3}$. The minimum values of $\mathrm{O}_{3}\left(50-55 \mu \mathrm{g} \mathrm{m}^{-3}\right)$ are found in regions of chemically-driven high- $\mathrm{NO}_{\mathrm{x}}$ regime such as large polluted cities or within the shipping routes, Great Britain and The Netherlands, and in northernmost Europe due to the association of low precursor emissions and polar-like weather types. The $\mathrm{O}_{3}$ distribution described in this section is in accordance with the EMEP model results for the year 2005 presented by Tarrasón et al. (2007). However, the rather coarse resolution used by the EMEP model $(50 \mathrm{~km} \times 50 \mathrm{~km})$ led to a less accurate simulation of the chemical transition between urban and background areas.

\subsubsection{Nitrogen dioxide}

High concentrations of $\mathrm{NO}_{2}$ within the PBL are directly related to anthropogenic emissions (EEA, 2007). The largest contributors to $\mathrm{NO}_{2}$ atmospheric concentrations are the emissions from road transport (40\% of $\mathrm{NO}_{2}$ total emission) followed by power plants and other fuel converters $\left(22 \%\right.$ of $\mathrm{NO}_{2}$ total emission, Tarrasón et al., 2006). High modeled $\mathrm{NO}_{2}$ concentrations $\left(\sim 20-30 \mu \mathrm{g} \mathrm{m}^{-3}\right)$ are reported in The Netherlands and Belgium, the industrial Po Valley (northern 
Italy), central and eastern England, and the Ruhr region (western Germany). Various important European cities even reach $\mathrm{NO}_{2}$ levels up to $30-40 \mu \mathrm{g} \mathrm{m}^{-3}$ on annual average (e.g., Milan, London, Paris). Suburban areas surrounding the major cities often undergo advections of polluted air masses and display mean annual values near 10-25 $\mu \mathrm{g} \mathrm{m}^{-3}$ while clean regions unaffected by emissions rather have concentrations below $5 \mu \mathrm{g} \mathrm{m}^{-3}$. Also note that the major shipping routes originating from the North Sea, passing by the English Channel, through Portugal, Spain and northern Africa toward the Suez Canal substantially affect the coastal $\mathrm{NO}_{2}$ concentrations with a maximum of $18 \mu \mathrm{g} \mathrm{m}^{-3}$ for the annual mean concentrations. Qualitative comparisons between the simulated pattern of annual $\mathrm{NO}_{2}$ and satellite-derived $\mathrm{NO}_{2}$ tropospheric column densities from GOME (Beirle et al., 2004), SCIAMACHY and OMI (Boersma et al., 2007) revealed good agreement (not shown). Such finding demonstrates the relative accuracy in the spatial description of the source regions and various European hot-spots.

\subsubsection{Sulfur dioxide}

Simulated $\mathrm{SO}_{2}$ annual average concentrations over Europe (Fig. 7c) show highest levels over northwestern Spain, eastern Europe (Poland, Serbia, Rumania, Bulgaria and Greece), and over UK, Belgium and the southwestern part of The Netherlands. Combustion emissions from power plants and transformation industries are the main responsible for such high concentrations of $\mathrm{SO}_{2}$ over Europe. $64 \%$ of $\mathrm{SO}_{2}$ total emissions are attributed to these sectors (Tarrasón et al., 2006). The highest annual concentrations $\left(\sim 70-90 \mu \mathrm{g} \mathrm{m}^{-3}\right)$ are observed in northern Spain due to the presence of two large power plant installations. However, background regions in Spain remain below mean concentrations of $2 \mu \mathrm{g} \mathrm{m}^{-3}$. On the other hand, east European countries are affected by higher background concentrations of $\mathrm{SO}_{2}\left(\sim 8\right.$ to $\left.20 \mu \mathrm{g} \mathrm{m}^{-3}\right)$ with various punctual emissions contributing to an increase of the regional concentrations $\left(\sim 30\right.$ to $\left.50 \mu \mathrm{g} \mathrm{m}^{-3}\right)$. Over sea, the highest concentrations are found along the main shipping routes, as emissions from ships largely contribute to the $\mathrm{SO}_{\mathrm{x}}$ concentrations due to combustion of fuels with high sulfur content (Corbett and Fischbeck, 1997; Corbett and Koehler, 2003).

The distribution of mean annual $\mathrm{SO}_{2}$ concentrations for 2004 shows the same pattern as that presented by Tarrasón et al. (2007) for 2005. However, note that the $\mathrm{SO}_{2}$ levels have decreased according to the pattern shown in Schaap et al. (2004) for the year 1995. Indeed, from the mid-1990s to 2004, $\mathrm{SO}_{2}$ concentrations in air have strongly decreased due to reductions in $\mathrm{SO}_{\mathrm{x}}$ emissions. $\mathrm{SO}_{\mathrm{x}}$ emissions have reduced up to $50 \%$ mainly in the sectors of power and heat generation through a combination of using fuels with lower sulfur content (such as switching from 
coal and oil to natural gas) and implementing emission abatement strategies in the energy supply and industry sectors (EEA, 2007; International Maritime Organization and Marine Environment Protection Committee, 2001).

\subsubsection{Particulate matter}

The simulated spatial distribution of annual mean PM2.5 (Fig. 7d) shows average background levels around 3-10 $\mu \mathrm{g} \mathrm{m}^{-3}$ in northwestern, central and eastern Europe. Very low concentrations correspond to remote marine air and the major European mountain chains (e.g., the Alps, Massif Central, the Pyrenees and the Carpathians). The concentration levels are dominated by SIA, namely sulfate, nitrate and ammonium (not shown here). SSA does not substantially contribute to the PM2.5 fraction. The most polluted European region is the Po Valley with annual mean values near 14-22 $\mu \mathrm{g} \mathrm{m}^{-3}$. To a lesser extent, in the Benelux region (Belgium, The Netherlands, Luxembourg) high concentrations of PM2.5 are found $\left(\sim 8-12 \mu \mathrm{g} \mathrm{m}^{-3}\right)$. Such concentrations are mainly associated with primary anthropogenic emissions from road traffic and secondary aerosols. As mentioned in Sect. 3.2.3 Bulgaria, Rumania and Poland are important contributors of $\mathrm{SO}_{2}$. At the hot-spot locations, the large sulfate formation and primary PM emissions lead to annual mean concentrations of up to $20-22 \mu \mathrm{g} \mathrm{m}^{-3}$. Interestingly, the large sources of $\mathrm{SO}_{2}$ located in eastern UK and northwestern Spain do not contribute efficiently to the PM2.5 formation. Such low sulfate formation is most likely caused by high dispersion and strong removal by wet deposition in these regions. The north African continent constitutes a very large potential source of PM for the rest of the domain. During episodes of Saharan dust outbreaks, mineral dust largely contributes to the levels of PM2.5 in southern Europe.

Fig. 8a and Fig. 8b present the annual mean and 1-hour maximum of PM10 concentrations in Europe, respectively. PM10 includes the PM2.5 fraction, the primary anthropogenic coarse fraction $\left(\mathrm{PM}_{10-2.5}\right)$, as well as the contribution of coarse SSA and Saharan dust. Among other uncertainties, wind-blown or resuspended dust emissions (coarse fraction) are not taken into account yet. Such sources contribute to the underestimation of the total concentrations of PM10, especially in dry regions or in urban areas (see Amato et al., 2009a,b).

High mean and maximum values of annual PM10 concentrations found in the North Sea and the nearshore Atlantic result from SSA production. The mean contribution of SSA in the Mediterranean Sea reaches around $10 \mu \mathrm{g} \mathrm{m}^{-3}$. The annual mean contribution of the anthropogenic coarse fraction remains low $\left(\sim 5 \mu \mathrm{g} \mathrm{m}^{-3}\right)$ and is located at or in the vicinity of important emission sources (not shown). Saharan dust is responsible for the very high levels of PM in northern Africa and 
also regularly affects the Mediterranean basin and southern Europe. Spain, southern France, Italy, and Greece are particularly affected by such episodes. Fig. 8b reflects well the importance of including Saharan dust model data (on a nonclimatic basis) since dust outbreaks lead to annual maximum concentrations of PM10 greater than $300 \mu \mathrm{g} \mathrm{m}^{-3}$ in most of the territories surrounding the Mediterranean Sea.

Qualitatively, the spatial distributions of PM2.5 and PM10 show similar patterns to distributions found in other European modeling studies including sea salt and Saharan dust emissions (see, e.g., POLYPHEMUS and the Unified EMEP model, Sartelet et al., 2007; Tarrasón et al., 2006). Substantial differences arise in concentrations over southern Europe when comparing spatial distributions with models not taking dust from the African continent into account (see Bessagnet et al., 2004).

\section{Comparison with Other Evaluation Studies}

There are several air pollution modeling systems on the European scale operated routinely in Europe. Evaluations of these regional air quality models with ground-based measurements were carried out either individually or in comparison to other models. The following discussion presents a comparative analysis between various European model evaluations and CALIOPE-EU. This analysis does not attempt to be an intercomparison study because the studies were performed under different conditions (simulated year, meteorological data, boundary conditions, emissions, etc.). However, it provides a good basis for assessing the reliability of the results obtained in the context of the European evaluation models. Table 5 shows a chronological list of published evaluation studies, which are presented along with CALIOPE-EU evaluation results.

The presented evaluation studies have several characteristics in common. First, they were carried out over Europe on a regional scale with horizontal resolutions in the range of $25-55 \mathrm{~km} \times \mathrm{km}$. Second, the simulations were run over a long period, mainly a year. The given models were evaluated against ground-based observations at rural locations from EMEP or AIRBASE databases. Also note that these evaluation studies were performed using statistical methods.

Most of the studies presented here, evaluated independently in previous publications, focused on both gas and particulate phases. These studies comprise: LOTOS-EUROS (Schaap et al., 2008), POLYPHEMUS (Sartelet et al., 2007), Unified EMEP (Tarrasón et al., 2006; Yttri et al., 2006), and CHIMERE (Bessagnet et al., 2004; Schmidt et al., 2001). In the case of the Unified EMEP model, 
Table 5: List of published European model evaluation studies and their main characteristics to be compared with CALIOPE-EU evaluation results (this study). A study code for each model is specified to ease the discussion in this paper.

\begin{tabular}{|c|c|c|c|c|}
\hline Reference & $\begin{array}{l}\text { Modeled } \\
\text { year }\end{array}$ & $\begin{array}{l}\text { Model } \\
\text { name }\end{array}$ & $\begin{array}{l}\text { Horizontal resolution } \\
\text { /layers }\end{array}$ & Study code \\
\hline This study & 2004 & CALIOPE-EU & $12 \mathrm{~km} \times 12 \mathrm{~km} / 15$ & CALIOPE-EU04 \\
\hline Matthias (2008) & 2001 & CMAQ & $54 \mathrm{~km} \times 54 \mathrm{~km} / 20$ & CMAQ2 \\
\hline Schaap et al. (2008) & 1999 & LOTOS-EUROS & $25 \mathrm{~km} \times 25 \mathrm{~km}$ & LOTOS-EUROS3 \\
\hline Sartelet et al. (2007) & 2001 & POLYPHEMUS & $0.5^{\circ} \times 0.5^{\circ} / 5$ & POLYPHEMUS4 \\
\hline van Loon et al. (2007) & 1999 & Unified EMEP & $50 \mathrm{~km} \times 50 \mathrm{~km} / 20$ & EMEP5 \\
\hline van Loon et al. (2007) & 1999 & $\mathrm{RCG}$ & $0.5^{\circ} \times 0.5^{\circ} / 5$ & RCG5 \\
\hline van Loon et al. (2007) & 1999 & LOTOS-EUROS & $0.5^{\circ} \times 0.5^{\circ} / 4$ & LOTOS-EUROS5 \\
\hline van Loon et al. (2007) & 1999 & CHIMERE & $0.5^{\circ} \times 0.5^{\circ} / 8$ & CHIMERE5 \\
\hline van Loon et al. (2007) & 1999 & MATCH & $0.4^{\circ} \times 0.4^{\circ} / 14$ & MATCH5 \\
\hline Tarrasón et al. (2006) & 2004 & Unified EMEP & $50 \mathrm{~km} \times 50 \mathrm{~km} / 20$ & EMEP6 \\
\hline Yttri et al. (2005) & 2004 & Unified EMEP & $50 \mathrm{~km} \times 50 \mathrm{~km} / 20$ & EMEP7 \\
\hline Bessagnet et al. (2004) & 1999 & CHIMERE & $0.5^{\circ} \times 0.5^{\circ} / 8$ & CHIMERE8 \\
\hline van Loon et al. (2004) & $1999 / 2001$ & CHIMERE & $0.5^{\circ} \times 0.5^{\circ} / 8$ & CHIMERE9 \\
\hline van Loon et al. (2004) & $1999 / 2001$ & DEHM & $50 \mathrm{~km} \times 50 \mathrm{~km} / 20$ & DEHM9 \\
\hline van Loon et al. (2004) & $1999 / 2001$ & Unified EMEP & $50 \mathrm{~km} \times 50 \mathrm{~km} / 20$ & EMEP9 \\
\hline van Loon et al. (2004) & $1999 / 2001$ & MATCH & $55 \mathrm{~km} \times 55 \mathrm{~km} / 10$ & MATCH9 \\
\hline van Loon et al. (2004) & $1999 / 2001$ & LOTOS & $0.25^{\circ} \times 0.5^{\circ} / 3$ & LOTOS9 \\
\hline van Loon et al. (2004) & $1999 / 2001$ & CMAQ & $36 \mathrm{~km} \times 36 \mathrm{~km} / 21$ & CMAQ9 \\
\hline van Loon et al. (2004) & $1999 / 2001$ & REM-CALGRID & $0.25^{\circ} \times 0.5^{\circ}$ & REM-CALGRID9 \\
\hline Schaap et al. (2004) & 1995 & LOTOS & $25 \mathrm{~km} \times 25 \mathrm{~km} / 3$ & LOTOS 10 \\
\hline Hass et al. (2003) & 1995 & DEHM & $50 \mathrm{~km} \times 50 \mathrm{~km} / 10$ & DEHM11 \\
\hline Hass et al. (2003) & 1995 & EURAD & $27 \mathrm{~km} \times 27 \mathrm{~km} / 15$ & EURAD11 \\
\hline Hass et al. (2003) & 1995 & EUROS & $0.55^{\circ} \times 0.55^{\circ} / 4$ & EUROS11 \\
\hline Hass et al. (2003) & 1995 & LOTOS & $0.25^{\circ} \times 0.5^{\circ} / 3$ & LOTOS11 \\
\hline Hass et al. (2003) & 1995 & MATCH & $55 \mathrm{~km} \times 55 \mathrm{~km} / 10$ & MATCH11 \\
\hline Hass et al. (2003) & 1995 & REM3 & $0.25^{\circ} \times 0.5^{\circ}$ & REM11 \\
\hline Schmidt et al. (2001) & 1998 & CHIMERE & $0.5^{\circ} \times 0.5^{\circ} / 5$ & CHIMERE12 \\
\hline
\end{tabular}


evaluation studies are being processed every year since 1980 (Tarrasón et al., 2005). For the purpose of this paper, we only exploited their evaluation of the year 2004, since it is the reference year modeled by CALIOPE-EU. The single evaluations of both CMAQ (Matthias, 2008) and LOTOS (Schaap et al., 2004) only focused on particulate matter results.

In addition to the models evaluated independently and listed above, three model intercomparisons were also carried out and are presented in Table 5. In the framework of EUROTRAC (Hass et al., 2003) the authors evaluated the ability of six models to simulate inorganic aerosol compounds. In the review of the Unified EMEP model (van Loon et al., 2004) the gas and particulate phases from seven models were compared. More recently, an intercomparison was performed in order to study the response of five models to different emission scenarios in terms of $\mathrm{O}_{3}$ levels (EURODELTA project, van Loon et al., 2007).

Table 6 and Table 7 present the statistics of each reviewed study available for the gas $\left(\mathrm{O}_{3}, \mathrm{NO}_{2}\right.$ and $\left.\mathrm{SO}_{2}\right)$ and particulate (PM10 and PM2.5) phases, respectively. Three statistical parameters are considered, namely the annual daily means of MNBE, $r$, and RMSE. These parameters were calculated without threshold on the measurement data, except for the MNBE value of $\mathrm{O}_{3}$ in POLYPHEMUS4 which is calculated using a threshold of $80 \mu \mathrm{g} \mathrm{m}^{-3}$ as pointed out by Sartelet et al. (2007). The displayed results represent the annual means at all considered stations. Values in parentheses, when available, correspond to the minimum and maximum performances at individual stations.

For the $\mathrm{O}_{3}$ daily mean CALIOPE-EU presents satisfactory annual MNBE values in comparison to the other studies $\left(6 \mu \mathrm{g} \mathrm{m}^{-3}\right.$ versus $\left.2-29 \mu \mathrm{g} \mathrm{m}^{-3}\right)$. The annual daily mean correlation is rather low ( 0.66 versus $0.53-0.83)$. Nevertheless, the RMSE obtained with CALIOPE-EU is in the range of other models (20.6 $\mu \mathrm{g}$ $\mathrm{m}^{-3}$ for CALIOPE-EU versus 18.4-28.1 $\mu \mathrm{g} \mathrm{m}^{-3}$ ). Values for the annual daily peak mean correlations for CALIOPE-EU are slightly below the range of the other studies. Note that the CMAQ9 model obtained the same annual daily peak mean correlation as CALIOPE-EU, namely 0.69 versus $0.71-0.84$, which is lower than in the other studies. However, for individual stations, CALIOPE-EU remains within the same range of EMEP6 for the year 2004 (0.28-0.82 versus 0.10-0.84). This large range of values reflects the high variability of the model performances depending on the region of the domain (see Fig. 4 and discussion in Sect. 3.1.1). RMSE and MNBE values for annual daily peak mean of $\mathrm{O}_{3}$ lie within the range of the other models.

Overall, the CALIOPE-EU performances for $\mathrm{NO}_{2}$ are superior to other models. The annual daily mean correlation obtained in this study is the highest from 
Table 6: Comparison of the statistics Mean Normalized Bias Error (MNBE, \%), correlation (r), and Root Mean Squared Error (RMSE, $\left.\mu \mathrm{g} \mathrm{m}^{-3}\right)$ between CALIOPE-EU and other European models ${ }^{a, b}$ for gas phase $\left(\mathrm{O}_{3}, \mathrm{NO}_{2}\right.$ and $\mathrm{SO}_{2}$ daily and $\mathrm{O}_{3}$ daily peak). The statistics do not consider thresholds on measurement data except for the MNBE value $\left(^{*}\right)$ provided by the POLYPHEMUS study.

\begin{tabular}{|c|c|c|c|c|c|c|c|c|c|c|c|c|}
\hline \multirow[t]{2}{*}{ Study Number } & \multicolumn{3}{|c|}{$\mathrm{O}_{3}$ daily average } & \multicolumn{3}{|c|}{$\mathrm{O}_{3}$ daily peak average } & \multicolumn{3}{|c|}{$\mathrm{NO}_{2}$ daily average } & \multicolumn{3}{|c|}{$\mathrm{SO}_{2}$ daily average } \\
\hline & MNBE & $\mathrm{r}$ & RMSE & MNBE & $\mathrm{r}$ & RMSE & MNBE & $\mathrm{r}$ & RMSE & MNBE & $\mathrm{r}$ & RMSE \\
\hline CALIOPE-EU04 & $\begin{array}{c}6 \\
(-22,43)\end{array}$ & $\begin{array}{c}0.66 \\
(0.06,0.81)\end{array}$ & $\begin{array}{c}20.6 \\
(15.8 .29 .2)\end{array}$ & $\begin{array}{c}-3 \\
(-23,23)\end{array}$ & $\begin{array}{c}0.69 \\
(0.28,0.82)\end{array}$ & $\begin{array}{c}21.8 \\
(17.5 .30 .7)\end{array}$ & $\begin{array}{c}-17 \\
(-74.77)\end{array}$ & $\begin{array}{c}0.67 \\
(0.02,0.84)\end{array}$ & $\begin{array}{c}10.1 \\
(1.4 .36 .3)\end{array}$ & $\begin{array}{c}83 \\
(-28.370)\end{array}$ & $\begin{array}{c}0.60 \\
(0.13,0.80)\end{array}$ & $\begin{array}{c}2.2 \\
(0.8,6.4)\end{array}$ \\
\hline LOTOS-EUROS3 & & 0.65 & 25.2 & & 0.75 & 20.4 & & 0.40 & 11.4 & & 0.40 & 3.4 \\
\hline POLYPHEMUS4 & & & & $-14^{*}$ & 0.72 & 21.4 & & 0.33 & 10.0 & & 0.47 & 5.0 \\
\hline EMEP5 & 10 & 0.72 & & 1 & 0.75 & & & & & & & \\
\hline RCG5 & 3 & 0.71 & & 7 & 0.76 & & & & & & & \\
\hline LOTOS-EUROS5 & 2 & 0.7 & & 7 & 0.76 & & & & & & & \\
\hline CHIMERE5 & 29 & 0.76 & & 10 & 0.84 & & & & & & & \\
\hline MATCH5 & 6 & 0.8 & & 2 & 0.81 & & & & & & & \\
\hline EMEP6 & 10 & 0.72 & & 1 & $\begin{array}{c}0.75 \\
(0.10,0.84)\end{array}$ & & & & & & 0.67 & \\
\hline CHIMERE8 & & & & & & & $(-78,349)$ & $(-0.30,0.70)$ & $(1.0,28.0)$ & & & \\
\hline CHIMERE9 & & $0.78 / 0.83$ & 18.4/18.1 & & $0.78 / 0.83$ & $18.4 / 18.1$ & & $0.47 / 0.44$ & $12.6 / 13.9$ & & $0.37 / 0.47$ & $10.9 / 10.1$ \\
\hline DEHM9 & & $0.66 / 0.66$ & $24.2 / 23.1$ & & $0.78 / 0.78$ & $22.1 / 21.7$ & & $0.45 / 0.46$ & $11.1 / 11.7$ & & $0.43 / 0.49$ & $4.8 / 3.9$ \\
\hline EMEP9 & & $0.63 / 0.65$ & $23.6 / 23.0$ & & $0.75 / 0.76$ & 19.1/19.5 & & $0.43 / 0.45$ & $11.2 / 12.1$ & & $0.40 / 0.42$ & $4.7 / 3.9$ \\
\hline MATCH9 & & $0.65 / 0.68$ & $24.7 / 24.5$ & & $0.79 / 0.80$ & $18.3 / 18.8$ & & $0.42 / 0.44$ & $11.8 / 12.5$ & & $0.43 / 0.48$ & $4.4 / 3.2$ \\
\hline LOTOS9 & & $0.53 / 0.54$ & $27.7 / 28.1$ & & $0.74 / 0.73$ & $21.7 / 22.0$ & & $0.25 / 0.30$ & $12.9 / 13.6$ & & $0.24 / 0.45$ & $5.9 / 4.6$ \\
\hline CMAQ9 & & $0.55 /-$ & 32.6/- & & $0.69 /-$ & $25.5 /-$ & & $0.52 /-$ & 10.8/- & & $0.44 /-$ & $6.0 /-$ \\
\hline REM-CALGRID9 & & $0.61 / 0.64$ & $26.4 / 25.7$ & & $0.71 / 0.74$ & $21.9 / 22.0$ & & $0.40 / 0.42$ & $11.9 / 12.6$ & & $0.35 / 0.39$ & $4.7 / 3.5$ \\
\hline LOTOS10 & & & & & & & & & & & 0.48 & 4.1 \\
\hline DEHM11 & & & & & & & & 0.23 & 8.7 & & 0.43 & 2.8 \\
\hline EURAD11 & & & & & & & & 0.16 & 8.9 & & 0.39 & 5.6 \\
\hline EUROS11 & & & & & & & & 0.07 & 9.4 & & 0.39 & 3.9 \\
\hline LOTOS11 & & & & & & & & 0.03 & 9.2 & & 0.39 & 3.1 \\
\hline MATCH11 & & & & & & & & 0.23 & 8.5 & & 0.45 & 2.7 \\
\hline REM311 & & & & & & & & 0.13 & 9.3 & & 0.35 & 3.3 \\
\hline CHIMERE12 & & & & & $(0.51,0.88)$ & $(13.4,44.6)$ & & $(-0.05,0.77)$ & $(1.0,10.0)$ & & & \\
\hline
\end{tabular}

${ }^{a}$ Value reported without parenthesis represents the annual average in the entire domain. The first and second values in parenthesis represent the minimum and maximum values respectively obtained among all stations in the entire domain. ${ }^{b}$ Values reported before and after a slash correspond to the year 1999 and 2001, respectively. 
Table 7: Comparison of the statistics MNBE (\%), $\mathrm{r}$ and RMSE $\left(\mu \mathrm{g} \mathrm{m}^{-3}\right)$ between CALIOPEEU and other European models ${ }^{a, b}$ for particulate matter PM2.5 and PM10. The statistics do not consider thresholds on measurement data.

\begin{tabular}{|c|c|c|c|c|c|c|}
\hline \multirow[t]{2}{*}{ Study Number } & \multicolumn{3}{|c|}{ PM2.5 daily average } & \multicolumn{3}{|c|}{ PM10 daily average } \\
\hline & MNBE & $\mathrm{r}$ & RMSE & MNBE & $\mathrm{r}$ & RMSE \\
\hline CALIOPE-EU04 & $\begin{array}{c}-45 \\
(-68,-13)\end{array}$ & $\begin{array}{c}0.47 \\
(0.46,0.79)\end{array}$ & $\begin{array}{c}11.2 \\
(5.5,25.3)\end{array}$ & $\begin{array}{c}-50 \\
(-72,12)\end{array}$ & $\begin{array}{c}0.57 \\
(0.10,0.77)\end{array}$ & $\begin{array}{c}15.8 \\
(5.7,31.4)\end{array}$ \\
\hline CMAQ2 & & & & & $(0.35,0.69)$ & \\
\hline POLYPHEMUS4 & & 0.54 & 8.6 & & 0.54 & 12.6 \\
\hline EMEP7 & & $\begin{array}{c}0.44 \\
(0.28,0.7)\end{array}$ & 10.6 & & $\begin{array}{c}0.48 \\
(0.24,0.66)\end{array}$ & 14.1 \\
\hline CHIMERE8 & & & & $(-80,20)$ & $(0.50,0.70)$ & $(0.8,30.0)$ \\
\hline CHIMERE9 & & & & & $0.55 / 0.55$ & $14.4 / 13.8$ \\
\hline DEHM9 & & & & & $0.50 / 0.49$ & $16.0 / 14.5$ \\
\hline EMEP9 & & & & & $0.52 / 0.48$ & $15.7 / 14.9$ \\
\hline MATCH9 & & & & & $0.44 / 0.49$ & $14.9 / 12.9$ \\
\hline LOTOS9 & & & & & $0.45 / 0.38$ & $16.6 / 15.2$ \\
\hline CMAQ9 & & & & & $0.54 /-$ & $15.0 /-$ \\
\hline REM-CALGRID9 & & & & & $0.57 / 0.49$ & $13.2 / 12.4$ \\
\hline LOTOS 10 & & & & & $(0.35,0.69)$ & \\
\hline
\end{tabular}

${ }^{a}$ Value reported without parentheses represents the annual average in the entire domain. The first and second values in parenthesis represent the minimum and maximum values respectively obtained among all stations in the entire domain. ${ }^{b}$ Values reported before and after a slash correspond to the year 1999 and 2001, respectively. 
all considered models (0.67 versus $0.03-0.47)$. The annual daily mean RMSE value is among the lowest $\left(10.0 \mu \mathrm{g} \mathrm{m}^{-3}\right.$ versus $\left.8.5-13.9 \mu \mathrm{g} \mathrm{m}^{-3}\right)$. MNBE values for CALIOPE-EU are similar to CHIMERE8, the only study providing $\mathrm{NO}_{2}$ annual daily mean values. Such a broad range of MNBE values is caused by the sensitivity to low observed concentrations, inducing problems of inflation and asymmetry (Yu et al., 2006). Therefore, we encourage future modeling studies to use threshold-filtered MNBE for $\mathrm{NO}_{2}$ or else use fractional errors instead. The high performances of CALIOPE-EU with $\mathrm{NO}_{2}$ is attributed mostly to the high resolution of the model system which enables a well-defined spatial and temporal description of $\mathrm{NO}_{2}$ sources throughout Europe.

As with $\mathrm{NO}_{2}$, the CALIOPE-EU evaluation results for $\mathrm{SO}_{2}$ show very satisfactory performances in comparison to the other studies. The calculated RMSE is the lowest from all models $\left(2.2 \mu \mathrm{g} \mathrm{m}^{-3}\right.$ against 2.7-10.9 $\left.\mu \mathrm{g} \mathrm{m}^{-3}\right)$. Additionally the annual daily mean correlation obtained for CALIOPE-EU is the second highest value after the EMEP6 study with $\mathrm{r}=0.60$ against 0.67 , respectively. The other studies calculated lower correlation coefficients between 0.24 and 0.49 . No annual daily mean MNBE values were provided by the other evaluations. Also, the $\mathrm{SO}_{2}$ model performances are mainly attributed to the high resolution of the CALIOPE-EU system enhancing the simulation accuracy. As mean background concentrations of observed $\mathrm{SO}_{2}$ in Europe are low $\left(\sim 2 \mu \mathrm{g} \mathrm{m}^{-3}\right.$, see Table 3), mean normalized errors may not adequately represent the performances of a model at rural sites. In that case, the use of thresholds on observational data or rather MFE and MFB should be considered.

Considering PM2.5, the model performance on the annual mean correlation coefficient is comparable with the two other studies POLYPHEMUS4 and EMEP7 ( 0.49 versus 0.44 and 0.54$)$. Such correlation is rather low and reflects the high uncertainties in the sources of fine particles (see discussion in Sect. 3.1.4). The annual daily mean RMSE obtained by CALIOPE-EU is slightly higher than the values obtained by the two other studies $\left(11.0 \mu \mathrm{g} \mathrm{m}^{-3}\right.$ versus 8.6 and $10.6 \mu \mathrm{g}$ $\left.\mathrm{m}^{-3}\right)$.

Statistics for PM10 are in the same range as for the other studies. As with all other models, CALIOPE-EU tends to underestimate the PM10 concentrations, with the calculation of PM2.5 concentrations being a substantial source of underestimation. Per individual stations, the MNBE range for CALIOPE-EU is similar to that of CHIMERE8 (from $-72 \%$ to $12 \%$ compared to $-80 \%$ to $20 \%$ for CHIMERE8). The calculated annual daily mean correlation coefficient of this work is the highest value from all other studies, together with the REMCALGRID9 study for the year 1999. The annual daily mean RMSE remains in 
the range of other studies (15.7 $\mu \mathrm{g} \mathrm{m}^{-3}$ versus 12.4-16.6 $\mu \mathrm{g} \mathrm{m}^{-3}$ )

Overall, the performances on the levels and variability of particulate matter are relatively poor, but this intercomparison shows that the underestimated mean concentrations and the lack of understanding on the formation processes is a general feature affecting most models.

The results of this intercomparison suggest that CALIOPE-EU performs relatively well for the simulation of $\mathrm{O}_{3}$ concentrations while high scores were obtained for $\mathrm{NO}_{2}$ and $\mathrm{SO}_{2}$. In general, performances on particulate matter (PM2.5 and PM10) are satisfactory in comparison to the other studies. However, substantial efforts should be made in the chemical description of PM formation and the accuracy of PM sources.

From this model inter-comparison it was noticed that model systems based on the CMAQ chemical model (CALIOPE-EU and CMAQ9) perform better for daily mean $\mathrm{NO}_{2}$ and $\mathrm{SO}_{2}$ than for $\mathrm{O}_{3}$ daily average and daily peak averages when compared to the other systems. While most European models obtain $\mathrm{O}_{3}$ annual mean daily peak correlations between 0.7 and 0.8 for the year 2004, both CMAQ models reach a maximum of 0.69 . However, note that this correlation obtained by CALIOPE-EU is higher than values reported by other studies using CMAQ and representing the US domain (see, e.g., Zhang et al., 2006; Yu et al., 2006; Eder and $\mathrm{Yu}, 2006)$. On the other hand, the correlations for $\mathrm{NO}_{2}$ and $\mathrm{SO}_{2}$ are notably higher for CMAQ models than for the other chemical models. All models are based on the same emissions from the EMEP database, but the disaggregation techniques or additional integrated modules may differ. These results indicate some potential limitations with the chemical mechanism used within this version of CMAQ (CBM-IV) when applied to the EMEP emissions over Europe (also see Emmerson and Evans, 2009). The Carbond Bond mechanism has recently been updated (Yarwood et al., 2005) and evaluated (Luecken et al., 2008). It is expected that the latest mechanism, namely CB05, could improve the behaviour of the CMAQ model over rural European areas considering the efforts done to improve the simulations under low $\mathrm{NO}_{\mathrm{x}}$ conditions.

Another relevant issue that arises from the model comparison is the impact of horizontal resolution. As stated before in the text, all models are forced with EMEP emissions. These emissions have a spatial resolution of $50 \mathrm{~km} \times 50 \mathrm{~km}$. After different spatial disaggregation techniques most models perform similarly regardless of the target horizontal resolution. This result is not surprising if one considers that this evaluation focuses on rural environments limited by NOx. The horizontal resolution may impact urban and industrial areas at a higher degree than rural areas. In this sense, the higher horizontal resolution of CALIOPE- 
EU system may be responsible for the better scores obtained in $\mathrm{NO}_{2}$ and $\mathrm{SO}_{2}$. It is reasonable to think that a detailed emission inventory at a finer horizontal resolution could further improve the air quality model performances.

Finally, the vertical resolution of the models presented in this evaluation ranges from 3 to 20 vertical layers. It is expected that models with higher vertical levels are able to simulate the vertical mixing better. However, the statistics do not show a direct relationship with the model vertical resolution. That implies that various systems are strongly driven by surface emissions, and vertical exchange is not directly resolved though strongly parameterized.

\section{Conclusions}

This paper presented the evaluation results of the model system CALIOPEEU (namely WRF-ARW/HERMES-EMEP/CMAQ/BSC-DREAM8b) using a full year simulation for 2004 over a European domain. The evaluation focused on the capability of the model to reproduce the temporal and spatial distribution of pollutants, estimating their uncertainty and comparing them with other European evaluation studies. This article evaluated gas $\left(\mathrm{O}_{3}, \mathrm{NO}_{2}\right.$ and $\left.\mathrm{SO}_{2}\right)$ and particulate phase (PM10 and PM2.5) simulations with EMEP ground-based measurements. It is noteworthy mentioning that neither correction factors nor any adjusting model parameterization were applied to the model output or the original model codes. Only in the case of particulate matter, adjusted levels were discussed in order to quantify the missing source apportionment.

CALIOPE-EU was able to reproduce the observed $\mathrm{O}_{3}$ annual cycle. Moreover, CALIOPE-EU simulated the general features of $\mathrm{O}_{3}$ fields over Europe, especially the differences between urban and background levels. In general, daily maxima were better simulated than daily averages, and summertime concentrations were better simulated than wintertime concentrations. The conditions at the lateral boundaries of the model domain were shown to strongly affect the evolution of $\mathrm{O}_{3}$ throughout the year, especially at the stations near the boundaries and during wintertime. These conditions should be handled with care, as they occasionally lead to excessive $\mathrm{O}_{3}$ concentrations near the surface. In CMAQ, the construction of boundary profiles from global chemistry models, in that case the LMDz-INCA2, should integrate the information of the tropopause in the downscaling process to avoid strong downdrafts of $\mathrm{O}_{3}$-enriched air masses down to the surface.

Concerning $\mathrm{NO}_{2}$, the annual trend was moderately well simulated with a systematic negative bias. High correlations were obtained over either very clean or 
highly polluted areas (stations around the Baltic Sea or UK). On average, the model underestimated both background levels and peaks, especially during winter and over high polluted areas where transport dominates compared to chemical processes. From the results of the annual pattern, CALIOPE-EU was able to simulate maximum concentrations over most important emission sources in Europe, since concentrations sharply decrease from urban-suburban to rural areas.

The model system was able to reproduce the annual variability of daily mean concentrations for background $\mathrm{SO}_{2}$ throughout Europe. Monthly variations of $\mathrm{SO}_{2}$ were well captured, especially from January to March, but false peaks were reported. Vertical mixing characteristics and the way emissions are distributed within the grid are potential key issues which may explain the overestimation detected in simulated $\mathrm{SO}_{2}$. The spatial distribution of statistics showed low mean bias values with heterogeneous correlation coefficients. The spatial $\mathrm{SO}_{2}$ pattern successfully represented the main European sources (in the vicinity of energy and transformation industries and shipping routes).

By comparing model results with measurements of PM2.5 and PM10 it was found that CALIOPE-EU reproduces most of the pollution events. However, the model underestimated the observed values of PM2.5 and PM10. In order to identify the origin of such discrepancies and to determine the sources of uncertainty, the aerosol chemical composition should be evaluated. Among other sources not accounted for, particulate matter emissions from paved road re-suspension and wind blown dust should be included in order to reduce the systematic biases. When a multiplying factor of 2 was applied to both simulated PM2.5 and PM10, MFE and MFB statistics lied within the performance goal defined by Boylan and Russell (2006). Moreover, the contribution of seasonal natural particulate matter, marine and Saharan mineral dust, was well characterized. Introducing dust aerosol outbreaks on a non-climatic basis with BSC-DREAM8b was essential for the simulation of hourly peaks during dust outbreaks, especially in southern Europe.

When compared to other European models CALIOPE-EU performed reasonably well for ozone annual daily mean and daily peak concentrations. $\mathrm{O}_{3}$ statistics lie within the US-EPA guidelines although annual correlations are rather low compared to other European models. On the other hand, statistics for $\mathrm{NO}_{2}, \mathrm{SO}_{2}$, PM10 and PM2.5 present higher scores than most models. We noted a similar behaviour with the other CMAQ-based modelling system; both systems present lower annual correlations for $\mathrm{O}_{3}$ while results of $\mathrm{NO}_{2}, \mathrm{SO}_{2}, \mathrm{PM} 2.5$ and PM10 are higher than other systems.

The horizontal resolution of CALIOPE-EU provided high details in the spa- 
tial distribution and temporal evolution of most relevant gas-phase and particulate matter pollutants. Sharp and concentrated plumes and other sub-grid scale processes were represented correctly. Although emission data are based on the disaggregation from the EMEP inventory (emissions at $50 \mathrm{~km} \times 50 \mathrm{~km}$ ), the results are within the range of most European models.

This study warrants the use of the CALIOPE-EU system over Europe and results will be used as boundary conditions for the high-resolution air quality simulation over the Iberian peninsula at a $4 \mathrm{~km} \times 4 \mathrm{~km}$ resolution.

\section{Acknowledgements}

The authors wish to thank EMEP for the provision of measurement stations and CIEMAT, CSIC-IJA, CEAM centers for their collaboration in the project. Also, thanks to C. Pérez, E. Lopez and L. González for their work related to the CALIOPE system as well as S. Szopa and A. Cozic for the provision of LMDz-INCA2 chemical data. This work is funded by the CALIOPE project of the Spanish Ministry of the Environment (441/2006/3-12.1, A357/2007/2-12.1, 157/PC08/3-12.0). All simulations were performed on the MareNostrum supercomputer hosted by the Barcelona Supercomputing Center.

\section{References}

Adams, L.I., Davis, J., Japar, S.M., Finley, D.R., 1990. Real-time, in situ measurements of atmospheric optical absorption in the visible via photoacoustic spectroscopy iv. visibility degradation and aerosol optical properties in los angeles. Atmos. Environ. 24A, 605610.

Amato, F., Pandolfi, M., Escrig, A., Querol, X., Alastuey, A., Pey, J., Perez, N., Hopke, P.K., 2009a. Quantifying road dust resuspension in urban environment by multilinear engine: A comparison with pmf2. Atmos. Environ. 43, 27702780 .

Amato, F., Pandolfi, M., Escrig, A., Querol, X., Alastuey, A., Pey, J., Perez, N., Hopke, P.K., 2009b. Quantifying road dust resuspension in urban environment by multilinear engine: A comparison with pmf2. Atmos. Environ. 43, 27702780, doi:10.1016/j.atmosenv.2009.02.039.

Baldasano, J.M., Güereca, L.P., López, E., Gassó, S., Jimenez-Guerrero, P., 2008a. Development of a high-resolution ( $1 \mathrm{~km} \mathrm{x} 1 \mathrm{~km}, 1 \mathrm{~h})$ emission model 
for spain: The high-elective resolution modelling emission system (hermes). Atmos. Environ. 42, 7215-7233.

Baldasano, J.M., Jiménez-Guerrero, P., Jorba, O., Pérez, C., López, E., Güereca, P., Martín, F., Vivanco, M.G., Palomino, I., Querol, X., Pandolfi, M., Sanz, M.J., Diéguez, J.J., 2008b. Caliope: an operational air quality forecasting system for the iberian peninsula, balearic islands and canary islands - first annual evaluation and ongoing developments. Adv. Sci. Res. 2, 89-98.

Beck, J., Grennfeld, P., 1993. Distribution of ozone over europe, in: the Proceedings of the EUROTRAC Symposium, pp. 43-58.

Beirle, S., Platt, U., Wenig, M., Wagner, T., 2004. Highly resolved global distribution of tropospheric $\mathrm{NO}_{2}$ using gome narrow swath mode data. Atmos. Chem. Phys. 4, 1913-1924.

Bessagnet, B., Hodzic, A., Vautard, R., Beekmann, M., Cheinet, S., Honoré, C., Liousse, C., Rouill, L., 2004. Aerosol modeling with chimere-preliminary evaluation at the continental scale. Atmos. Environ. 38, 2803-2817.

Binkowski, F.S., Roselle, S.J., 2003. Models-3 community multiscale air quality (cmaq) model aerosol component. 1. model description. J. Geophys. Res. 108 (D6), 4183, doi:10.1029/2001JD001409.

Binkowski, F.S., 1999. Aerosols in models-3 cmaq, in: Byun, D.W., Ching, J.K.S. (Eds.), Science Algorithms of the EPA Models-3 Community Multiscale Air Quality (CMAQ) Modeling System, EPA. pp. 10-0 - 10-23.

Boersma, K.F., Eskes, H.J., Veefkind, J.P., Brinksma, E.J., van der A, R.J., Sneep, M., van der Oord, G.H.J., Levelt, P.F., Stammes, P., Gleason, J.F., Bucsela, E.J., 2007. Near-real time retrieval of tropospheric $\mathrm{NO}_{2}$ from omi. Atmos. Chem. Phys. 7, 2103-2118.

Boylan, J., Russell, A., 2006. Pm and light extinction model performance metrics, goals, and criteria for three-dimensional air quality models. Atmos. Environ. 40, 4946-4959.

Byun, D.W., Ching, J.K.S., 1999. Science algorithms of the epa models-3 community multiscale air quality (cmaq) modeling system. Atmospheric modeling division, National Exposure Research Laboratory, US Environmental Protection Agency, Research Triangle Park, NC 27711. 
Byun, D., Schere, K.L., 2006. Review of the governing equations, computational algorithms, and other components of the models-3 community multiscale air quality (cmaq) modeling system. Appl. Mech. Rev. 59 (2), 51-77.

Chang, J.C., Hanna, S.R., 2004. Air quality model performance evaluation. Meteorol. Atmos. Phys. 87, 167-196.

Ching, J., Herwehe, J., Swall, J., 2006. On joint deterministic grid modeling and sub-grid variability conceptual framework for model evaluation. Atmos. Environ. 40, 4935-4945.

Chylek, P., Wong, J., 1995. Effect of absorbing aerosols on global radiation budget. Geophys. Res. Lett. 22 (8), 929-931, doi:10.1029/95GL00800.

Corbett, J.J., Fischbeck, P., 1997. Emissions from ships. Science 278 (5339), 823-824, doi:10.1126/science.278.5339.823.

Corbett, J.J., Koehler, H.W., 2003. Updated emissions from ocean shipping. J. Geophys. Res. 108 (D20), 4650, doi:10.1029/2003JD003751.

COST, 2009. Towards a European Network on Chemical Weather Forecasting and Information Systems (ENCWF). Technical Report. COST Action ES0602, Monitoring Progress Report.

Cox, W.M., Tikvart, J.A., 1990. Statistical procedure for determining the best performing air quality simulation model. Atmos. Environ. 24, 2387-2395.

Cristofanelli, P., Bonasoni, P., 2009. Background ozone in the southern europe and mediterranean area: Influence of the transport processes. Env. Poll. 157, 1399-1406.

De Meij, A., Krol, M., Dentener, F., Vignati, E., Cuvelier, C., Thunis, P., 2006. The sensitivity of aerosol in europe to two different emission inventories and temporal distribution of emissions. Atmos. Chem. Phys. 6, 42874309.

Dudhia, J., 1989. Numerical study of convection observed during the winter monsoon experiment using a mesoscale two-dimensional model. J. Atmos. Sci. 46 (20), 3077-3107, doi:10.1175/1520-0469.

Dyer, A.J., Hicks, B.B., 1970. Flux-gradient relationships in the constant flux layer. Q. J. R. Meteorol. Soc. 96 (410), 715721, doi:10.1002/qj.49709641012. 
Eder, B., Yu, S., 2006. A performance evaluation of the 2004 release of models-3 cmaq. Atmos. Environ. 40, 4811-4824, doi:10.1016/j.atmosenv.2005.08.045.

EEA, 2000. CORINE Land Cover, 2000. Technical Report. European Environmental Agency. http://dataservice.eea.eu.int/dataservice, February 2007.

EEA, 2005. Air pollution by ozone in Europe in summer 2004. Technical Report. 3/2005, Copenhagen, Denmark. http://reports.eea.eu.int.

EEA, 2007. Air pollution in Europe 1999-2004. Technical Report. 2/2007, Luxembourg, Office for Official Publications of the European Communities. 79 pp.

Eisele, H., Scheel, H.E., Sladkovic, R., Trickl, T., 1999. High-resolution lidar measurements of stratosphere-troposphere exchange. J. Atmos. Sci. 56, 319330 .

EMEP, 2007. National emissions reported to the Convention on Long-range Transboundary Air Pollution (LRTAP Convention). Air emission annual data reporting (EMEP/MSC-W). Technical Report. European Environmental Agency, The Norwegian Meteorological Institute, Oslo, Norway.

Emmerson, K.M., Evans, M.J., 2009. Comparison of tropospheric gas-phase chemistry schemes for use within global models. Atmos. Chem. Phys. 9, 18311845 .

ESRI, 2003. Europe Highways Cartography 2003. Technical Report. GIS de ESRI (ESRI España Geosistemas S.A: http://www.esri-es.com.

European Commission, 1996. Council Directive 96/62/EC of 27 September 1996 on ambient air quality assessment and management laid the foundations for a common strategy to define and establish objectives for ambient air quality. Technical Report 1996/62/EC, L296. Off. J. Eur. Comm.

European Commission, 1999. Council Directive 1999/30/EC of 22 April 1999 relating to limit values for sulphur dioxide, nitrogen dioxide and oxides of nitrogen, particulate matter and lead in ambient air. Technical Report 1999/30/EC, L 163. Off. J. Eur. Comm.

European Commission, 2001. Commission Decision of 17 October 2001 amending Annex V to Council Directive 1999/30/EC relating to limit values for sulphur dioxide, nitrogen dioxide and oxides of nitrogen, particulate matter and 
lead in ambient air (Text with EEA relevance) (notified under document number C(2001) 3091). Technical Report 2001/744/EC, 278. Off. J. Eur. Comm.

European Commission, 2002. Directive 2002/3/EC of the European Parliament and of the Council of 12 February 2002 relating to ozone in ambient air. Technical Report 2002/3/EC, L67. Off. J. Eur. Comm.

European Commission, 2008. Directive 2008/50/EC of the European Parliament and of the Council of 21 May 2008 on ambient air quality and cleaner air for Europe. Technical Report 2008/50/EC, L152. Off. J. Eur. Comm.

Folberth, G., Hauglustaine, D.A., Lathière, J., Brocheton, J., 2006. Interactive chemistry in the laboratoire de météorologie dynamique general circulation model: model description and impact analysis of biogenic hydrocarbons on tropospheric chemistry. Atmos. Chem. Phys. 6, 2273-2319.

Gerasopoulos, E., Kouvarakis, G., Vrekoussis, M., Kanakidou, M., Mihalopoulos, N., 2005. Ozone variability in the marine boundary layer of the eastern mediterranean based on 7-year observations. J. Geophys. Res. 110, D15309.

Gery, M.W., Whitten, G.Z., Killus, J.P., Dodge, M.C., 1989. A photochemical kinetics mechanism for urban and regional scale computer modeling. J. Geophys. Res. 94 (D10), 12925-12956.

Gong, S.L., 2003. A parameterization of sea-salt aerosol source function for sub- and super-micron particles. J. Geophys. Res. 17, 1097, doi:10.1029/2003GB002079.

Guerova, G., Bey, I., Attié, J.L., Martin, R.V., Cui, J., Sprenger, M., 2006. Impact of transatlantic transport episodes on summertime ozone in europe. Atmos. Chem. Phys. 6, 2057-2072.

Hass, H., van Loon, M., Kessler, C., Stern, R., Matthijsen, J., Sauter, F., Zlatev, Z., Langner, J., Foltescu, V., Schaap, M., 2003. Aerosol Modeling: Results and Intercomparison form European Regional scale Modeling Systems. Technical Report. EUROTRAC 2 Report, EUREKA Environmental Project, GLOREAM.

Hauglustaine, D.A., Hourdin, F., Jourdain, L., Filiberti, M.A., Walters, S., Lamarque, J.F., Holland, E.A., 2004. Interactive chemistry in the laboratoire de 
meteorologie dynamique general circulation model: Description and background tropospheric chemistry evaluation. J. Geophys. Res. D4 (D04314), doi:10.1029/2003JD003,957.

Hewitt, C.D., Griggs, D.J., 2004. Ensembles-based Predictions of Climate Changes and their Impacts. Technical Report. 1, Eos, 85.

Hong, S.Y., Dudhia, J., Chen, S.H., 2004. A revised approach to ice microphysical processes for the bulk parameterization of clouds and precipitation. Mon. Weather Rev. 132 (1), 103-120, doi:10.1175/1520-0493.

International Maritime Organization and Marine Environment Protection Committee, 2001. Prevention of air pollution from ships-Sulfur monitoring 2000. Technical Report. London.

Jacobson, M.Z., 2001. Global direct radiative forcing due to multicomponent anthropogenic and natural aerosols. J. Geophys. Res. 106 (D2), 1551-1568, doi:2000JD900514.

Janjic, Z.I., 1977. Pressure gradient force and advection scheme used for forecasting with steep and small scale topography. Contr. Atmos. Phys. 50, 186-199.

Janjic, Z.I., 1979. Forward-backward scheme modified to prevent twogrid-interval noise and its application in sigma coordinate models. Contr. Atmos. Phys. 52, 69-84.

Janjic, Z.I., 1984. Non-linear advection schemes and energy cascade on semistaggered grids. Mon. Weather Rev. 112, 1234-1245.

Janjic, Z.I., 1990. The step-mountain coordinate: Physical package. Mon. Weather Rev. 118, 1429-1443.

Janjic, Z.I., 1994. The step-mountain eta coordinate model: Further developments of the convection, viscous sublayer and turbulence closure schemes. Mon. Weather Rev. 122, 927-945.

Japar, S.M., Brachaczek, W.W., Gorse Jr., R.A., Norbeck, J.M., Pierson, W.R., 1986. The contribution of elemental carbon to the optical properties of rural atmospheric aerosols. Atmos. Environ. 20, 12811289. 
Jiang, W., Smyth, S., Giroux, E., Roth, H., Yin, D., 2006. Differences between cmaq fine mode particle and $\mathrm{pm}_{2.5}$ concentrations and their impact on model performance evaluation in the lower fraser valley. Atmos. Environ. 40, $4973-$ 4985.

Jiménez-Guerrero, P., Jorba, O., Baldasano, J.M., Gassó, S., 2008. The use of a modelling system as a tool for air quality management: Annual high-resolution simulations and evaluation. Sci. Tot. Env. 390, 323-340.

Jiménez, P., Baldasano, J.M., Dabdub, D., 2003. Comparison of photochemical mechanisms for air quality modelling. Atmos. Environ. 37 (30), 4179-4194, doi:10.1016/S1352-2310(03)00567-3.

Jiménez, P., Lelieveld, J., Baldasano, J.M., 2006. Multi-scale modeling of air pollutants dynamics in the northwestern mediterranean basin during a typical summertime episode. J. Geophys. Res. 111, (D18306), 1-21, doi:10.1029/2005JD006516.

Kain, J.S., Fritsch, J.M., 1990. A one-dimensional entraining/detraining plume model and its application in convective parameterization. J. Atmos. Sci. 47 (23), 27842802, doi:10.1175/1520-0469.

Kain, J.S., Fritsch, J.M., 1993. Convective parameterization for mesoscale models: The kain-fritcsh scheme, the representation of cumulus convection in numerical models, in: Emanuel, K.A., Eds., D.R. (Eds.), Amer. Meteor. Soc., pp. $165-170$.

Lam, Y.F., Fu, J.S., 2009. A novel downscaling technique for the linkage of global and regional air quality modeling. Atmos. Chem. Phys. 9, 9169-9185.

Larssen, S., Sluyter, R., Helmis, C., 1999. Criteria for EUROAIRNET, the EEA air quality monitoring and information network. Technical Report No. 12, http://reports.eea.eu.int/TEC12/en. European Environment Agency.

Lave, L., Seskin, E.P., 1970. Air pollution and human health. Science 169 (3947), 723-733, doi:10.1126/science.169.3947.723.

Lelieveld, J., Berresheim, H., Borrmann, S., Crutzen, P.J., Dentener, F.J., Fischer, H., Feichter, J., Flatau, P.J., Heland, J., Holzinger, R., Korrmann, R., Lawrence, M.G., Levin, Z., Markowicz, K.M., Mihalopoulos, N., Minikin, A., Ramanathan, V., de Reus, M., Roelofs, G.J., Scheeren, H.A., Sciare, J., 
Schlager, H., Schultz, M., Siegmund, P., Steil, B., Stephanou, E.G., Stier, P., Traub, M., Warneke, C., Williams, J., Ziereis, H., 2002. Global air pollution crossroads over the mediterranean. Science 298, $794-799$.

Lipfert, F.W., 1994. Air Pollution and Community Health - A Critical Review and Data Source Book. Van Nostrand Reinhold, New York, ISBN 0-442-01444-9, 576pp., 310-342.

Li, Q., Jacob, D.J., Bey, I., Palmier, P., Duncan, B.N., Field, B.D., Martin, R.V., Fiore, A.M., Yantosca, R.M., Parrish, D.D., Simmonds, P.G., Oltmans, S.J., 2002. Transatlantic transport of pollution and its effects on surface ozone in europe and north america. J. Geophys. Res. 107 (D13), 4166, doi:10.1029/2001JD001422.

Luecken, D.J., Phillips, S., Sarwar, G., Jang, C., 2008. Effects of using the cb05 vs. saprc99 vs. cb4 chemical mechanism on model predictions: Ozone and gas-phase photochemical precursor concentrations. Atmos. Environ. 42, $5805-5820$.

Matthias, V., 2008. The aerosol distribution in europe derived with the community multiscale air quality (cmaq) model: comparison to near surface in situ and sunphotometer measurements. Atmos. Chem. Phys. 8, 5077-5097.

Michalakes, J., Dudhia, J., Gill, D., Henderson, T., Klemp, J., Skamarock, W., Wang, W., 2004. The weather research and forecast model: Software architecture and performance, in: Mozdzynski, E.G. (Ed.), To appear in proceeding of the Eleventh ECMWF Workshop on the Use of High Performance Computing in Meteorology, 2529 October 2004, Reading, U.K.. p. 117124.

Mlawer, E.J., Taubman, S.J., Brown, P.D., Iacono, M.J., Clough, S.A., 1997. Radiative transfer for inhomogeneous atmosphere: Rrtm, a validated correlated-k model for the longwave. J. Geophys. Res. 102 (D14), 16663-16682.

Nenes, A., Pilinis, C., Pandis, S.N., 1998. Isorropia: A new thermodynamic equilibrium model for multiphase multicomponent inorganic aerosols. Aquatic Geochemistry 4 (1), 123-152, doi:10.1023/A:1009604003981.

Nickovic, S., Kallos, G., Papadopoulos, A., Kakaliagou, O., 2001. A model for prediction of desert dust cycle in the atmosphere. J. Geophys. Res. 106 (D16), 18113-18129, doi:10.1029/2000JD900794. 
Noh, Y., Cheon, W.G., Hong, S.Y., Raasch, S., 2003. Improvement of the kprofile model for the planetary boundary layer based on large eddy simulation data. Bound. Lay. Met. 107 (2), 401-427, doi:10.1023/A:1022146015946.

Paulson, C.A., 1970. The mathematical representation of wind speed and temperature profiles in the unstable atmospheric surface layer. J. Appl. Met. 9 (6), 857-861, doi:10.1175/1520-0450.

Pénard-Morand, C., Charpi, D., Raherison, C., Kopferschmitt, C., Caillaud, D., Lavaud, F., Annesi-Maesano, I., 2005. Long-term exposure to background air pollution related to respiratory and allergic health in schoolchildren. Clin. Exp. Allergy 35 (10), 1279-1287, doi:10.1111/j.1365-2222.2005.02336.

Pérez, C., Nickovic, S., Baldasano, J.M., Sicard, M., Rocadenbosch, F., Cachorro, V.E., 2006a. A long saharan dust event over the western mediterranean: Lidar, sun photometer observations, and regional dust modeling. J. Geophys. Res. 111 (D15214), 1-16, doi:10.1029/2005JD006579.

Pérez, C., Nickovic, S., Pejanovic, G., Baldasano, J.M., Ozsoy, E., 2006b. Interactive dust-radiation modeling: A step to improve weather forecasts. J. Geophys. Res. 111 (D16206), doi:10.1029/2005JD006717, 1-17.

Piot, M., Jorba, O., Jimenez, P., Baldasano, J.M., 2008. The role of lateral boundary conditions and boundary layer in air quality modelling system. Eos Trans. AGU 8, H212+, Abstract A41H-0212.

Pope, C.A.I., Ezzati, M., Dockery, D.W., 2009. Fine-particulate air pollution and life expectancy in the united states. The New England Journ. Med. 360, 376386.

Pregger, T., Friedrich, R., 2009. Effective pollutant emission heights for atmospheric transport modelling based on real-world information. Environ. Poll. 157 (2), 552-560.

Pulles, T., Kuenen, J., Pesik, J., Cadman, J., Wagner, A., 2006. EPER - The European Pollutant Emission Register. Technical Report. http://eper.eea.eu.int/eper.

Ramanathan, V., Crutzen, P.J., Kiehl, J.T., Rosenfeld, D., 2001. Aerosols, climate, and the hydrological cycle. Science 294 (5549), 2119-2124, doi:10.1126/science.1064034. 
Reidmiller, D.R., Fiore, A.M., Jaffe, D.A., Bergmann, D., Cuvelier, C., Dentener, F.J., N.Duncan, B., Folberth, G., Gauss, M., Gong, S., Hess, Jonson, J.E., Keating, T., Lupu, A., Marmer, E., Park, R., Schultz, M.G., Shindell, D.T., Szopa, S., Vivanco, M.G., Wild, O., Zuber, A., 2009. The influence of foreign vs. north american emissions on surface ozone in the us. Atmos. Chem. Phys. 9, $5027-5042$.

Roy, B., Mathur, R., Gilliland, A.B., Howard, S.C., 2007. A comparison of cmaqbased aerosol properties with improve, modis, and aeronet data. J. Geophys. Res. 112 (D14301), doi:10.1029/2006JD008085.

Russell, A., Dennis, R., 2000. Narsto critical review of photochemical models and modeling. Atmos. Environ. 34 (12-14), 2283-2324, doi:10.1016/S13522310(99)00468-9.

Sartelet, K.N., Debry, E., Fahey, K., Roustan, Y., Tombette, M., Sportisse, B., 2007. Simulation of aerosols and gas-phase species over europe with the polyphemus system: Part i. model-to-data comparison for 2001. Atmos. Environ. 41, 6116-6131.

Schaap, M., A.Timmermans, R.M., Roemer, M., Boersen, G.A.C., Builtjes, P., Sauter, F., Velders, G., Beck, J., 2008. The lotos-euros model: description, validation and latest developments. Intern. J. Environ. and Pollut. 32, 270-290.

Schaap, M., Gon, H.V.D., Dentener, F.J., Visschedijk, A.J.H., van Loon, M., ten Brink, H.M., Putaud, J.P., Guillaume, B., Liousse, C., Builtjes, P.J.H., 2004. Anthropogenic black carbon and fine aerosol distribution over europe. J. Geophys. Res. 109 (D18207), doi:10.1029/2003JD004330.

Schell, B., Ackermann, I.J., Hass, H., Binkowski, F.S., Ebel, A., 2001. Modeling the formation of secondary organic aerosol within a comprehensive air quality model system. J. Geophys. Res. 106 (D22), 28275-28293, doi:2001JD000384.

Schmidt, H., Derognat, C., Vautard, R., Beekmann, M., 2001. A comparison of simulated and observed ozone mixing ratios for the summer of 1998 in western europe. Atmos. Environ. 6, 6227-6297.

Seinfeld, J.H., Pandis, S.N., 1998. Atmospheric Chemistry and Physics. John Wiley \& Sons, New York, Chichester, Weinheim. 
Simpson, D.W., Yttri, K., Klimont, Z., Caseiro, A., Gelencser, A., Pio, C., Puxbaum, H., Legrand, M.R., 2007. Modelling carbonaceous aerosol over europe: analysis of the carbasol and emep ec/oc campaigns. J. Geophys. Res. 112 (D23S19), doi: 10.1029/2006JD0008158.

Simpson, D., Fagerli, H., Jonson, J., Tsyro, S., Wind, P., Tuovinen, J., 2003. Transboundary acidification and eutrophication and ground level ozone in Europe. Technical Report. EMEP Status Report 1/03, Part I: Unified EMEP model description. The Norwegian Meteorological Institute, Oslo, Norway.

Skamarock, W.C., Klemp, J.B., 2008. A time-split nonhydrostatic atmospheric model for weather research and forecasting applications. J. Comput. Phys. 227 (7), 3465-3485, doi:10.1016/j.jcp.2007.01.037.

Song, C.K., Byun, D.W., Pierce, R.B., Alsaadi, J.A., Schaack, T.K., Vukovich, F., 2008. Downscale linkage of global model output for regional chemical transport modeling: Method and general performance. J. Geophys. Res. 113, D08308, doi:10.1029/JD008951.

Stern, R., Builtjes, P., Schaap, M., Timmermans, R., Vautard, R., Hodzic, A., Memmesheimer, M., Feldmann, H., Renner, E., Wolke, R., Kerschbaumer, A., 2008. A model inter-comparison study focussing on episodes with elevated $\mathrm{pm}_{10}$ concentrations. Atmos. Environ. 42, 4567-4588, doi:10.1016/j.atmosenv.2008.01.068.

Szopa, S., Foret, G., Menut, L., Cozic, A., 2009. Impact of large scale circulation on european summer surface ozone and consequences for modelling forecast. Atmos. Environ. 43, 1189-1195.

Tang, Y., Carmichael, G.R., Thongboonchoo, N., Chai, T., Horowitz, L.W., Pierce, R.B., Al-Saadi, J.A., Pfister, G., Vukovich, J.M., Avery, M.A., Sachse, G.W., Ryerson, T.B., Holloway, J.S., Atlas, E.L., Flocke, F.M., Weber, R.J., Huey, L.G., Dibb, J.E., Streets, D.G., Brune, W.H., 2007. Influence of lateral and top boundary conditions on regional air quality prediction: A multiscale study coupling regional and global chemical transport models. J. Geophys. Res. 112, D10S18, 2083-2097, doi: 10.1029/2006JD007515.

Tang, Y., Lee, P., Tsidulko, M., Huang, H.C., McQueen, J.T., DiMego, G.J., Emmons, L.K., Pierce, R.B., Lin, H.M., Kang, D., Tong, D., Yu, S.C., Mathur, R., Pleim, J.E., Otte, T.L., Pouliot, G., Young, J.O., Schere, K.L., Davidson, P.M., 
2008. The impact of chemical lateral boundary conditions on cmaq predictions of tropospheric ozone over the continental united states. Environ. Fluid Mech. 9, (1), 43-58, doi:10.1007/s10652-008-9092-5.

Tarrasón, L., Benedictow, A., Fagerli, H., Jonson, J., Klein, H., van Loon, M., Simpson, D., Tsyro, S., Vestreng, V., Wind, P., 2005. Transboundary Acidification, Eutrophication and Ground Level Ozone in Europe in 2003. EMEP Status Report 1/05. Technical Report. EMEP. The Norwegian Meteorological Institute, Oslo, Norway.

Tarrasón, L., Fagerli, H., Jonson, J.E., Simpson, D., Benedictow, A., Klein, H., Vestreng, V., 2007. Transboundary Acidification, Eutrophication and Ground Level Ozone in Europe in 2005. Technical Report. EMEP Status Report 1/07. The Norwegian Meteorological Institute, Oslo, Norway.

Tarrasón, L., Fagerli, H., Klein, H., Simpson, D., Benedictow, A., Vestreng, V., Rigler, E., Emberson, L., Posch, M., Spranger, T., 2006. Transboundary Acidification, Eutrophication and Ground Level Ozone in Europe from 1990 to 2004. Technical Report. EMEP Status Report 1/06: to support the review of the Gothenburg Protocol. The Norwegian Meteorological Institute, Oslo, Norway.

Thibodeau, L.A., Reed, R.B., Bishop, Y.M.M., Kammerman, L.A., 1980. Air pollution and human health: A review and reanalysis. Environ. Health Perspec. $34,165-183$.

Torseth, K., Hov, O., 2003. The EMEP monitoring strategy 2004-2009. Technical Report 9/2003. EMEP/CCC.

Tsyro, S.G., 2005. To what extent can aerosol water explain the discrepancy between model calculated and gravimetric $\mathrm{PM}_{10}$ and $\mathrm{PM}_{2.5}$. Atmos. Chem. Phys. 5, 515-532.

Tsyro, S., Simpson, D., Tarrasón, L., Klimont, Z., Kupiainen, K., Pio, C., Yttri, K.E., 2007. Modeling of elemental carbon over europe. J. Geophys. Res. 112, D23S19.

U.S. EPA, 1984. Interim procedures for evaluating air quality models (revised). Technical Report. EPA-450/4-91-013. U.S. Environmental Protection Agency, Office of Air Quality Planning and Standards: Research Triangle Park, NC. 
U.S. EPA, 1991. Guideline for regulatory application of the urban airshed model. Technical Report. EPA-450/4-91-013. U.S. Environmental Protection Agency, Office of Air Quality Planning and Standards: Research Triangle Park, NC.

U.S. EPA, 2007. Guidance on the Use of Models and Other Analyses for Demonstrating Attaintment of Air Quality Goals for Ozone, PM2.5, and Regional Haze. Technical Report. EPA-454/B-07-002. U.S. Environmental Protection Agency, Office of Air Quality Planning and Standards: Research Triangle Park, NC.

van Loon, M., Roemer, M.G.M., Builtjes, P.J.H., Bessagnet, B., Rouilll, L., Christensen, J., Brandt, J., Fagerli, H., Tarrasón, L., Rodgers, I., 2004. Model intercomparison In the framework of the review of the Unified EMEP model. TNO Report. Technical Report. R2004/282. 53 pp.

van Loon, M., Vautard, R., Schaap, M., Bergstrom, R., Bessagnet, B., Brandt, J., Builtjes, P., Christensen, J., Cuvelier, C., Graff, A., Jonson, J.E., Krol, M., Langner, J., Roberts, P., Rouïl, L., Stern, R., Tarrasón, L., Thunis, P., Vignati, E., White, L., Wind, P., 2007. Evaluation of long-term ozone simulations from seven regional air quality models and their ensemble. Atmos. Environ. 41, 2083-2097, doi:10.1016/j.atmosenv.2006.10.073.

Vautard, R., Bessagnet, B., Chin, M., Menut, L., 2005a. On the contribution of natural aeolian sources to particulate matter concentrations in europe: Testing hypotheses with a modelling approach. Atmos. Environ. 39 (18), 3291-3303, doi:10.1016/j.atmosenv.2005.01.051.

Vautard, R., Honoré, C., Beekmann, M., Rouïl, L., 2005b. Simulation of ozone during the august 2003 heat wave and emission control scenarios. Atmos. Environ. 39 (16), 2957-2967, doi:10.1016/j.atmosenv.2005.01.039.

Vautard, R., Schaap, M., Bergström, R., Bessagnet, B., Brandt, J., Builtjes, P.J.H., Christensen, J.H., Cuvelier, C., Foltescu, V., Graff, A., Kerschbaumer, A., Krol, M., Roberts, P., Rouïl, L., Stern, R., Tarrason, L., Thunis, P., Vignati, E., Wind, P., 2009. Skill and uncertainty of a regional air quality model ensemble. Atmos. Environ. 43, 4822-4832, doi:10.1016/j.atmosenv.2008.09.083.

Webb, E.K., 1970. Profile relationships: The log-linear range, and extension to strong stability. Q. J. R. Meteorol. Soc. 96 (407), 67-90, doi:10.1002/qj.49709640708. 
Weil, J.C., Sykes, R.I., Venkatram, A., 1992. Evaluating air-quality models: review and outlook. J. Appl. Met. 31, 1121-1145.

Wesely, M.L., Hicks, B., 2000. A review of the current status of knowledge on dry deposition. Atmos. Environ. 34, 2261-2282.

Wyat Appel, K., Bhave, P.V., Gilliland, A.B., Sarwar, G., Roselle, S.J., 2008. Evaluation of the community multiscale air quality (cmaq) model version 4.5: Sensitivities impacting model performance; part ii particulate matter. Atmos. Environ. 42 (24), 6057-6066, doi:10.1016/j.atmosenv.2008.03.036.

Wyat Appel, K., Gilliland, A., Sarwar, G., Gilliam, R.C., 2007. Evaluation of the community multiscale air quality (cmaq) model version 4.5: Uncertainties and sensitivities impacting model performance: Part i - ozone. Atmos. Environ. 41 (40), 9603-9613.

Yarwood, G., Rao, S., Yocke, M., Whitten, G.Z., 2005. Updates to the Carbon Bond chemical mechanism: CB05. Technical Report RT-0400675, December, 8. Final Report to the US EPA.

Yttri, K.E., Aas, W., Forster, C., Torseth, K., Tsyro, S., Tarrasón, L., Simpson, D., Vestreng, V., Lazaridis, M., Kopanakis, I., Aleksandropoulou, V., Gehrig, R., Adams, M., Woodfield, M., Putaud, J., Schultz, M., 2006. Transboundary particulate matter in Europe. Technical Report. EMEP Status Report 4/06. The Norwegian Meteorological Institute, Oslo, Norway.

Yttri, K.E., Hanssen, J.E., Tsyro, S., Lazaridis, M., Facchini, M.C., Jennings, S.G., 2005. Transboundary particulate matter in Europe. Technical Report. EMEP Status Report 4/05. The Norwegian Meteorological Institute, Oslo, Norway.

Yu, S., Eder, B., Dennis, R., Chu, S., Schwartz, S., 2006. New unbiased symmetric metrics for evaluation of air quality models. Atmos. Sci. Lett. 7, 26-34.

Zhang, K., Knipping, E., Wexler, A., Bhave, P., Tonnesen, G., 2005. Size distribution of sea-salt emissions as a function of relative humidity. Atmos. Environ. 39, 3373-3379.

Zhang, Y., Liu, P., Pun, B., Seigneur, C., 2006. A comprehensive performance evaluation of mm5-cmaq for the summer 1999 southern oxidants study episode, 
1285 part iii: Diagnostic and mechanistic evaluations. Atmos. Environ. 40, 4856$1286 \quad$ 4873, doi:10.1016/j.atmosenv.2005.12.046. 

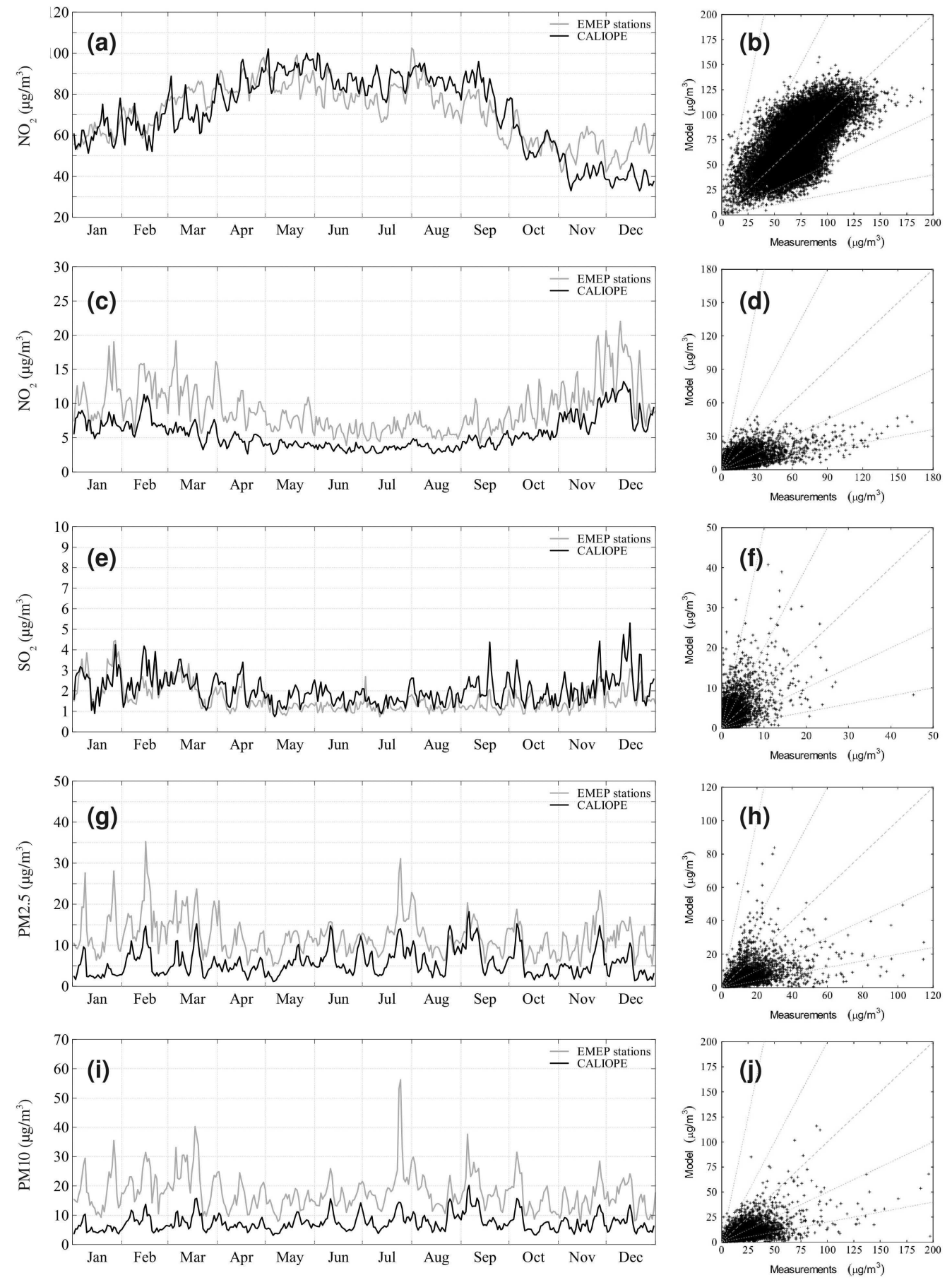

Figure 3: Modeled (black lines) and measured (grey lines) time series of daily mean concentrations (left) and scatter plots (right) for $\mathrm{O}_{3}, \mathrm{NO}_{2}, \mathrm{SO}_{2}, \mathrm{PM} 2.5$ and PM10, respectively, at the EMEP stations. The scatter plots include the $1: 1,1: 2,2: 1,1: 5$ and 5:1 reference lines. 

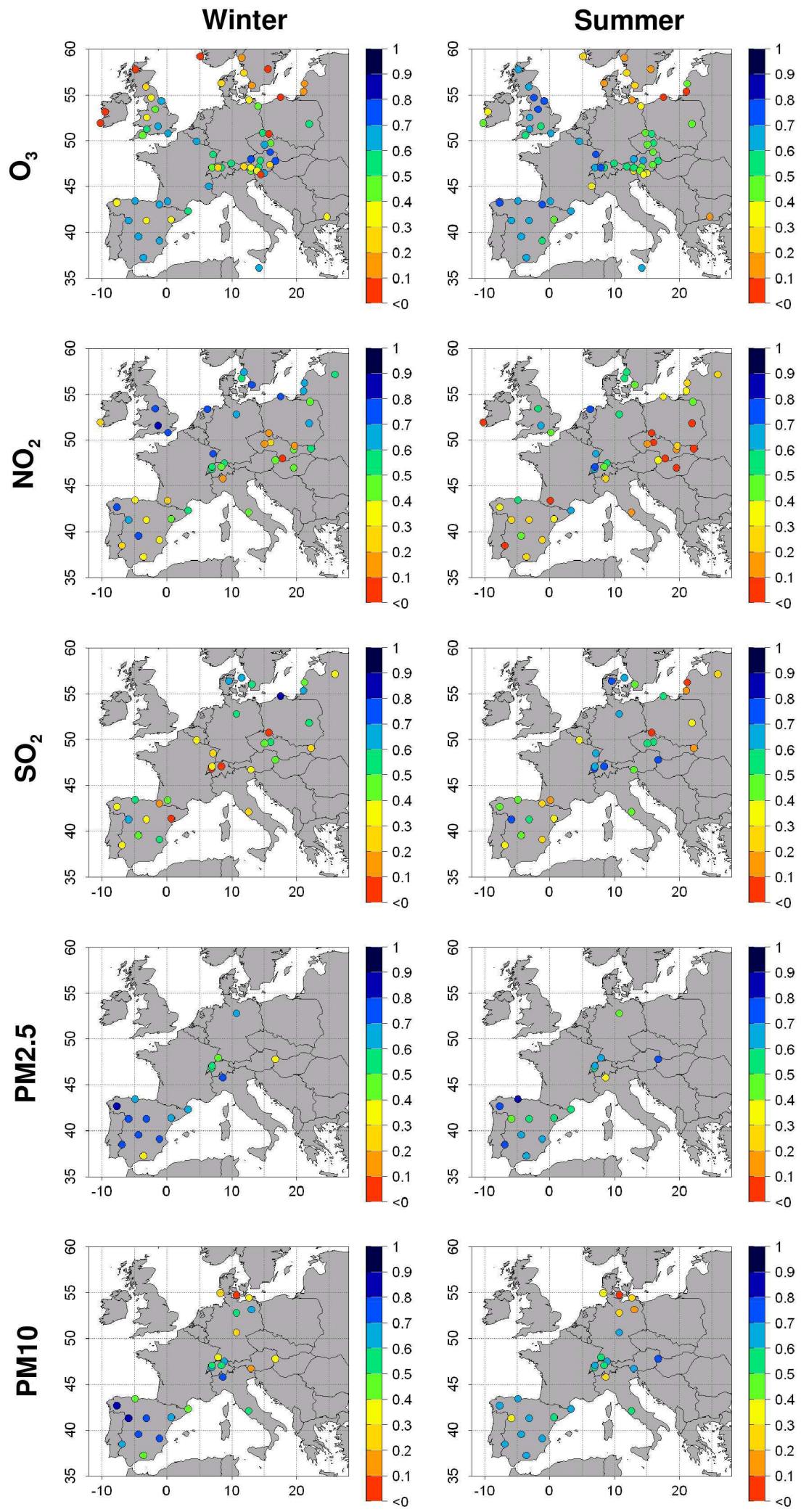

Figure 4: Spatial distribution of the correlation coefficient at all stations for $\mathrm{O}_{3}, \mathrm{NO}_{2}, \mathrm{SO}_{2}, \mathrm{PM} 2.5$ and PM10. The two columns represent the winter and summer seasons for 2004, respectively. 

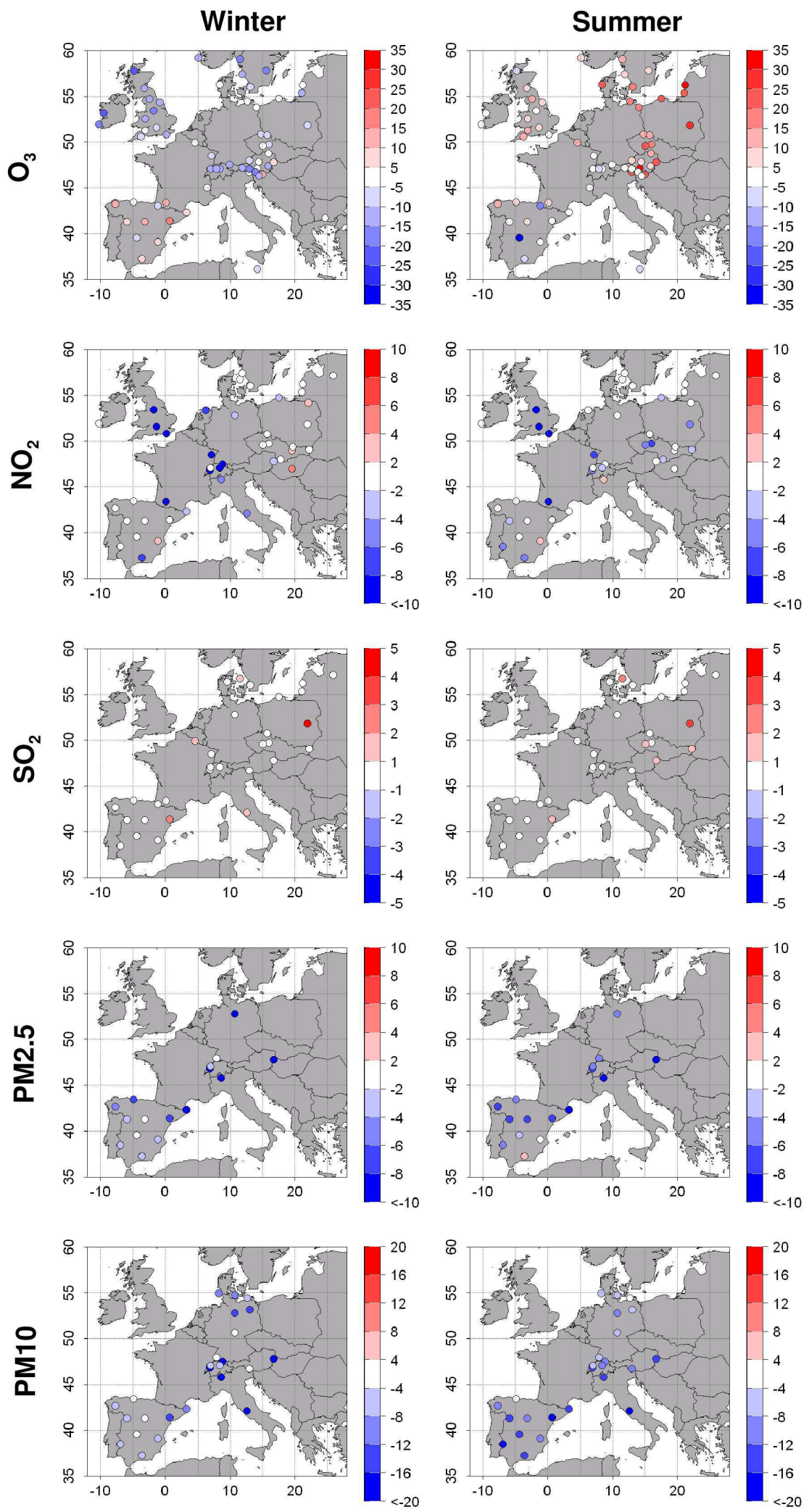

Figure 5: Spatial distribution of mean bias at all stations for $\mathrm{O}_{3}, \mathrm{NO}_{2}, \mathrm{SO}_{2}, \mathrm{PM} 2.5$ and PM10 (in $\mu \mathrm{g} \mathrm{m}^{-3}$ ). The two columns represent the winter and summer seasons for 2004 , respectively. 

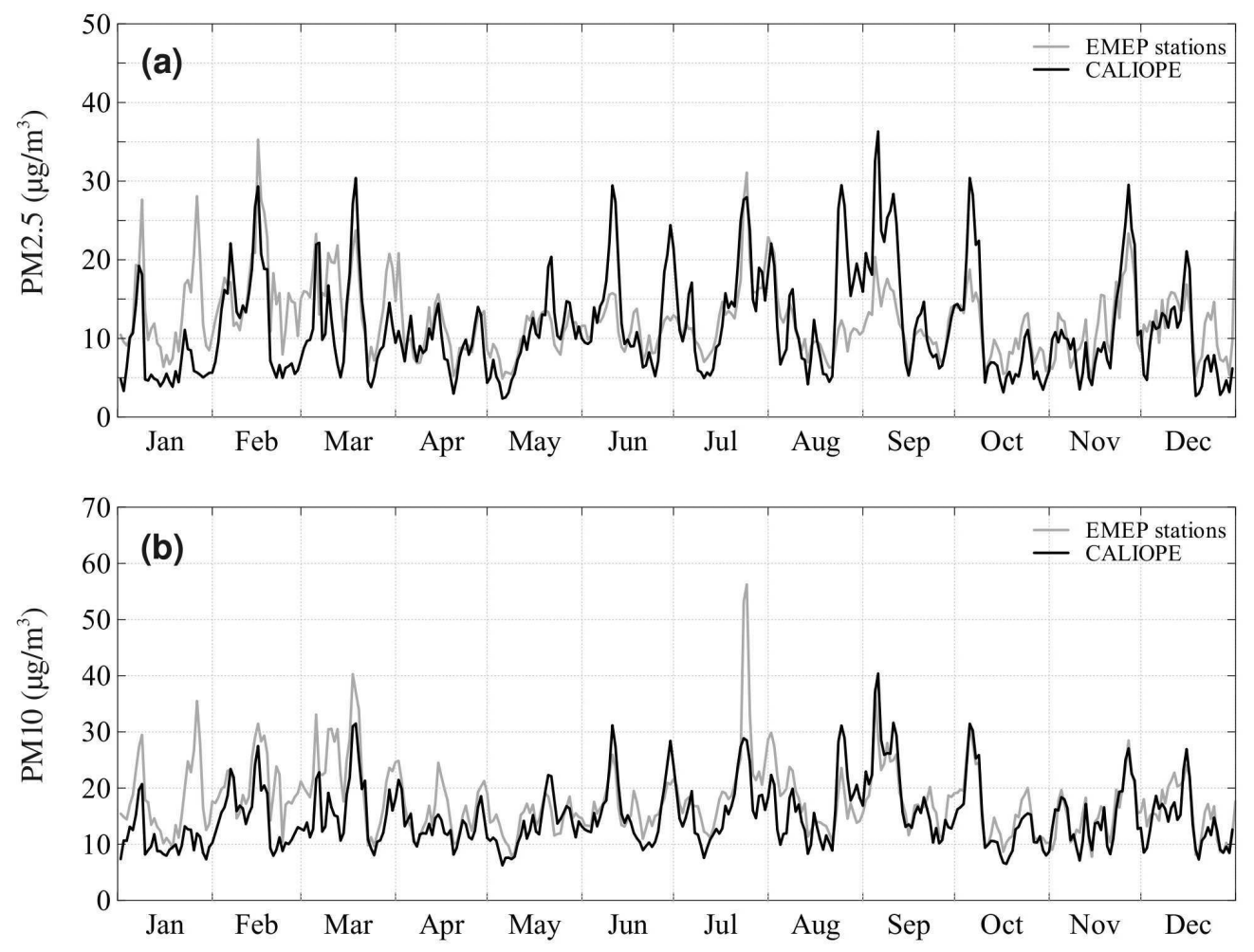

Figure 6: Modeled (black lines) and measured (grey lines) time series of daily mean concentrations for PM2.5 (top) and PM10 (bottom), multiplied by a correction factor of 2 at the EMEP stations. 

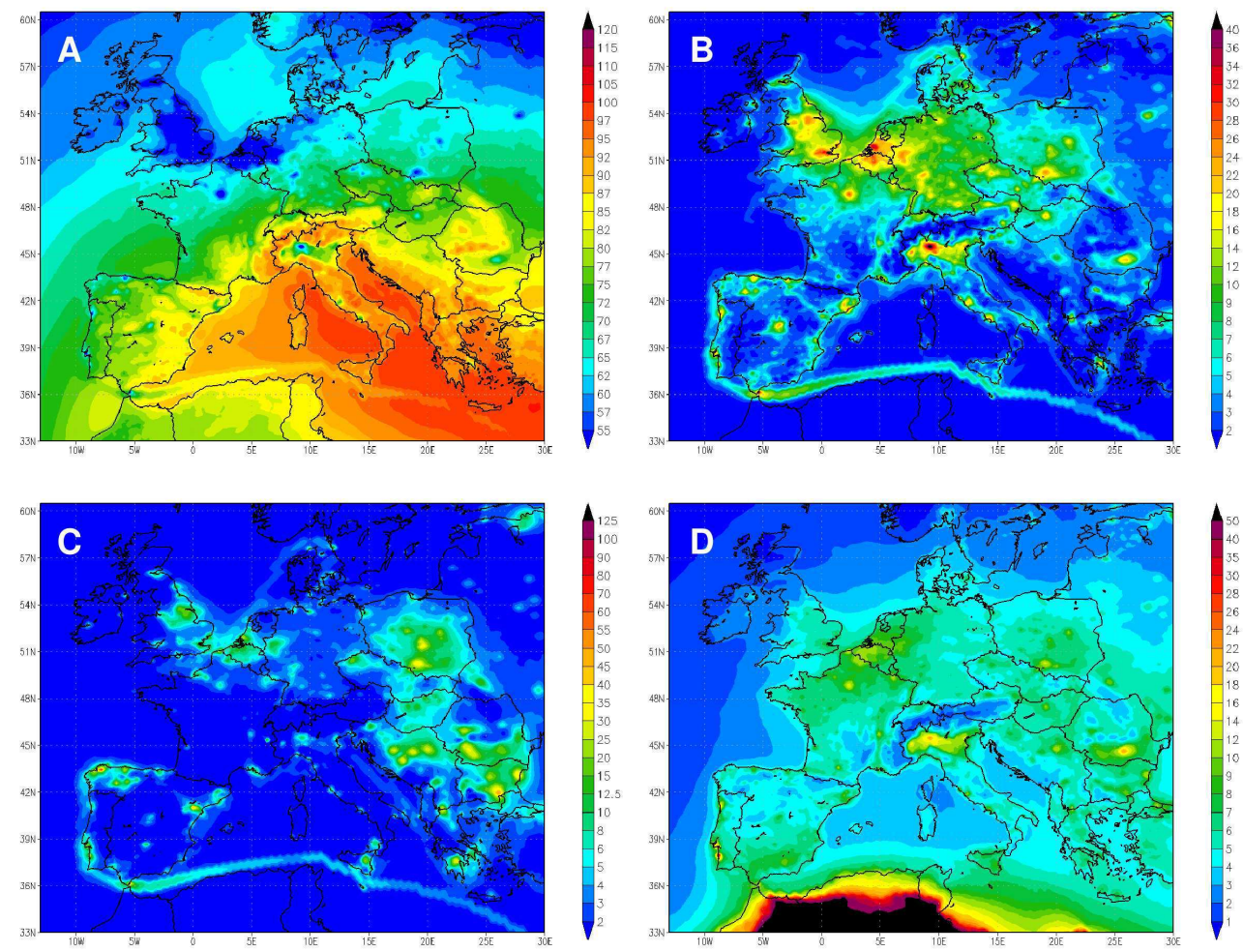

Figure 7: Simulated annual average concentrations $\left(\mu \mathrm{g} \mathrm{m}^{-3}\right.$ ) of (a) $\mathrm{O}_{3}$, (b) $\mathrm{NO}_{2}$, (c) $\mathrm{SO}_{2}$, (d) PM2.5 at ground level modeled with the CALIOPE-EU air quality modeling system for Europe with a $12 \mathrm{~km} \times 12 \mathrm{~km}$ spatial resolution in 2004 . 

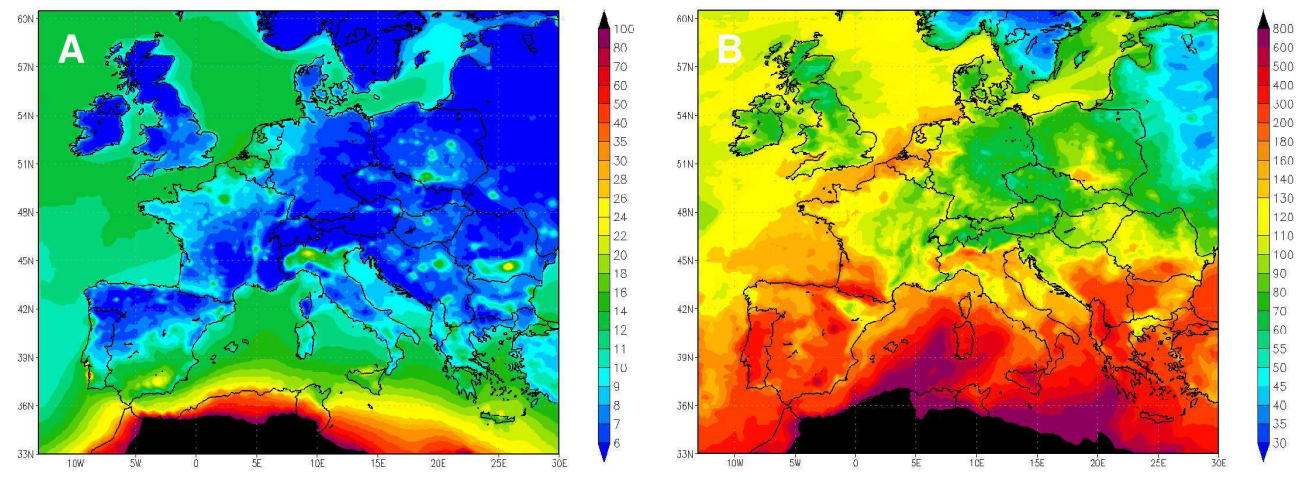

Figure 8: Simulated annual (a) average and (b) maximum concentrations for PM10 in $\mu \mathrm{g} \mathrm{m}^{-3}$ in 2004. 